University of Nebraska - Lincoln

DigitalCommons@University of Nebraska - Lincoln

Papers in the Earth and Atmospheric Sciences

Earth and Atmospheric Sciences, Department

2012

\title{
Holocene seasonal variability inferred from multiple proxy records from Crevice Lake, Yellowstone National Park, USA
}

\author{
Cathy Whitlock \\ Montana State University, whitlock@unca.edu \\ Walter E. Dean \\ U.S. Geological Survey \\ Sherilyn C. Fritz \\ University of Nebraska-Lincoln, sfritz2@unl.edu \\ Lora R. Stevens \\ California State University-Long Beach, lora.stevens@csulb.edu \\ Jeffery R. Stone \\ University of Nebraska-Lincoln, jeffery.stone@indstate.edu \\ See next page for additional authors
}

Follow this and additional works at: https://digitalcommons.unl.edu/geosciencefacpub

Part of the Earth Sciences Commons

Whitlock, Cathy; Dean, Walter E.; Fritz, Sherilyn C.; Stevens, Lora R.; Stone, Jeffery R.; Power, Mitchell J.; Rosenbaum, Joseph R.; Pierce, Kenneth L.; and Bracht-Flyr, Brandi B., "Holocene seasonal variability inferred from multiple proxy records from Crevice Lake, Yellowstone National Park, USA" (2012). Papers in the Earth and Atmospheric Sciences. 388.

https://digitalcommons.unl.edu/geosciencefacpub/388

This Article is brought to you for free and open access by the Earth and Atmospheric Sciences, Department of at DigitalCommons@University of Nebraska - Lincoln. It has been accepted for inclusion in Papers in the Earth and Atmospheric Sciences by an authorized administrator of DigitalCommons@University of Nebraska - Lincoln. 


\section{Authors}

Cathy Whitlock, Walter E. Dean, Sherilyn C. Fritz, Lora R. Stevens, Jeffery R. Stone, Mitchell J. Power, Joseph R. Rosenbaum, Kenneth L. Pierce, and Brandi B. Bracht-Flyr 


\title{
Holocene seasonal variability inferred from multiple proxy records from Crevice Lake, Yellowstone National Park, USA
}

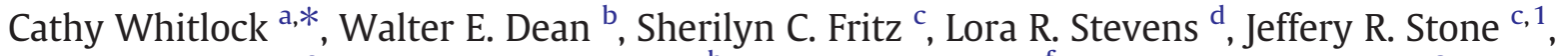 \\ Mitchell J. Power ${ }^{\text {e }}$, Joseph R. Rosenbaum ${ }^{\text {b }}$, Kenneth L. Pierce ${ }^{\mathrm{f}}$, Brandi B. Bracht-Flyr ${ }^{\mathrm{c}}$ \\ a Department of Earth Sciences, Montana State University Bozeman, MT, 59717, USA \\ b U.S. Geological Survey, MS 980 Federal Center, Denver, CO 80225, USA \\ c Department of Earth and Atmospheric Sciences, University of Nebraska, Lincoln, NE 68588, USA \\ d Department of Geological Sciences, California State University-Long Beach, Long Beach CA 90840, USA \\ e Department of Geography and Utah Museum of Natural History, University of Utah, Salt Lake City, UT 84112, USA \\ ${ }^{f}$ U.S. Geological Survey Northern Rocky Mountain Science Center, 2327 University Way, Box 2, Bozeman, MT 59715, USA
}

\section{A R T I C L E I N F O}

\section{Article history:}

Received 10 August 2011

Received in revised form 28 February 2012

Accepted 2 March 2012

Available online 11 March 2012

\section{Keywords:}

Yellowstone National Park

Varved sediments

Holocene

Pollen

Charcoal

Diatoms

Inorganic geochemistry

Mineralogy

Isotope geochemistry

Summer-wet climate

\begin{abstract}
A B S T R A C T
A 9400-yr-old record from Crevice Lake, a semi-closed alkaline lake in northern Yellowstone National Park, was analyzed for pollen, charcoal, geochemistry, mineralogy, diatoms, and stable isotopes to develop a nuanced understanding of Holocene environmental history in a region of northern Rocky Mountains that receives both summer and winter precipitation. The limited surface area, conical bathymetry, and deep water ( $>31 \mathrm{~m}$ ) of Crevice Lake create oxygen-deficient conditions in the hypolimnion and preserve annually laminated sediment (varves) for much of the record. Pollen data indicate that the watershed supported a closed Pinus-dominated forest and low fire frequency prior to $8200 \mathrm{cal} \mathrm{yr} \mathrm{BP}$, followed by open parkland until 2600 cal yr BP, and open mixed-conifer forest thereafter. Fire activity shifted from infrequent standreplacing fires initially to frequent surface fires in the middle Holocene and stand-replacing events in recent centuries. Low values of $\delta^{18} \mathrm{O}$ suggest high winter precipitation in the early Holocene, followed by steadily drier conditions after $8500 \mathrm{cal} \mathrm{yr} \mathrm{BP.} \mathrm{Carbonate-rich} \mathrm{sediments} \mathrm{before} 5000 \mathrm{cal}$ yr BP imply warmer summer conditions than after 5000 cal yr BP. High values of molybdenum (Mo), uranium (U), and sulfur (S) indicate anoxic bottom-waters before $8000 \mathrm{cal} \mathrm{yr}$ BP, between 4400 and $3900 \mathrm{cal}$ yr BP, and after $2400 \mathrm{cal}$ yr BP. The diatom record indicates extensive water-column mixing in spring and early summer through much of the Holocene, but a period between 2200 and 800 cal yr BP had strong summer stratification, phosphate limitation, and oxygen-deficient bottom waters. Together, the proxy data suggest wet winters, protracted springs, and warm effectively wet summers in the early Holocene and less snowpack, cool springs, warm dry summers in the middle Holocene. In the late Holocene, the region and lake experienced extreme changes in winter, spring, and summer conditions, with particularly short springs and dry summers and winters during the Roman Warm Period ( 2000 cal yr BP) and Medieval Climate Anomaly (1200-800 cal yr BP). Long springs and mild summers occurred during the Little Ice Age, and these conditions persist to the present. Although the proxy data indicate effectively wet summer conditions in the early Holocene and drier conditions in the middle and late Holocene, none point specifically to changes in summer precipitation as the cause. Instead, summer conditions were governed by multi-seasonal controls on effective moisture that operated over multiple time scales.
\end{abstract}

(c) 2012 Elsevier B.V. All rights reserved.

\section{Introduction}

The present climate of the northern Rocky Mountains previously has been broadly divided into two precipitation regimes, one that is strongly influenced by the northeast Pacific subtropical high-

\footnotetext{
* Corresponding author.

E-mail address: whitlock@montana.edu (C. Whitlock).

1 Current address: Climate Change Institute, University of Maine, Orono, ME 04473, USA.
}

pressure system in summer, and one with substantially more summer precipitation as a result of monsoonal circulation coming from the Gulf of Mexico and the subtropical Pacific (Mock, 1996). These regimes have been referred to as summer-dry and summer-wet, recognizing that winter and spring seasons contribute most of the annual precipitation received in the region (Whitlock and Bartlein, 1993). The geographic pattern of these precipitation regimes is clear at a continental scale, but spatial heterogeneity of current and past climate variations in mountainous regions is striking. Whitlock and Bartlein (1993) postulated that the location of so-called summer- 
wet and summer-dry regimes in the northern Rocky Mountains is and has been constrained by topography. They argue that the regimes were both intensified in the early Holocene as a result of the amplification of the seasonal cycle of insolation then. In summer-dry regions, increased summer insolation strengthened the northeastern Pacific subtropical high-pressure system, suppressing summer precipitation, whereas summer-wet regions became wetter than today as a result of stronger monsoonal circulation in the early Holocene. Thus, summerwet regions were wetter in the early Holocene than at present and summer-dry regions were drier than at present, but Whitlock and Bartlein (1993) suggest their relative geographic location (unlike their intensity) has not changed substantially.

Evaluation of the summer-wet/summer-dry hypotheses has rested primarily on pollen and charcoal data. Here, we provide further examination of the hypothesis by comparing a suite of climatic and environmental proxy measurements from a varved-sediment core from Crevice Lake in northern Yellowstone National Park (YNP) $(45.000 \mathrm{~N}, 110.578 \mathrm{~W}$, elev. $1684 \mathrm{~m})$. These measurements include proxies sensitive to winter snowpack and period of ice melt (stable isotopes of endogenic carbonate); spring water-column stratification and oxygen deficiency (diatoms and redox sensitive elements); organic productivity (diatoms, organic carbon, biogenic silica); terrestrial changes (pollen, charcoal, detrital influx); and hydroclimatic variability (stable oxygen isotopes). Our objective was to describe the various datasets collected at Crevice Lake and provide mutually consistent interpretations of the multiple indicators, recognizing that individual datasets may have alternative explanations. The Crevice Lake reconstruction is compared with other records from YNP and the northern Rocky Mountains to better understand regional environmental change during the Holocene.

\section{Site description}

Crevice Lake is a closed, groundwater-fed lake on the floor of the Black Canyon of the Yellowstone River in northern YNP (Fig. 1), located inside the limits of the late Pleistocene Greater Yellowstone glacial system and more than $65 \mathrm{~km}$ up-valley from the Pinedale terminal moraines (Pierce, 1979). Surrounding bouldery deposits with sandy
A

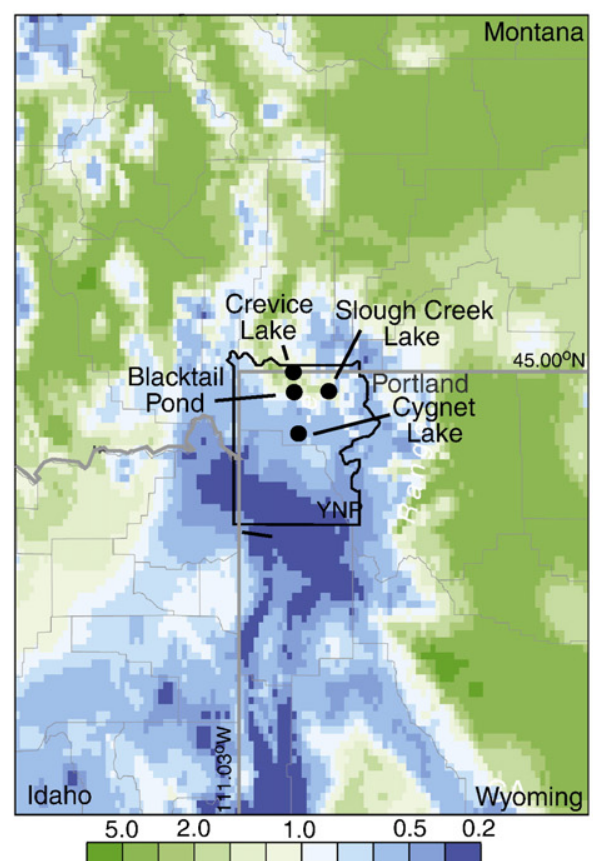

July / January Precipitation Ratio

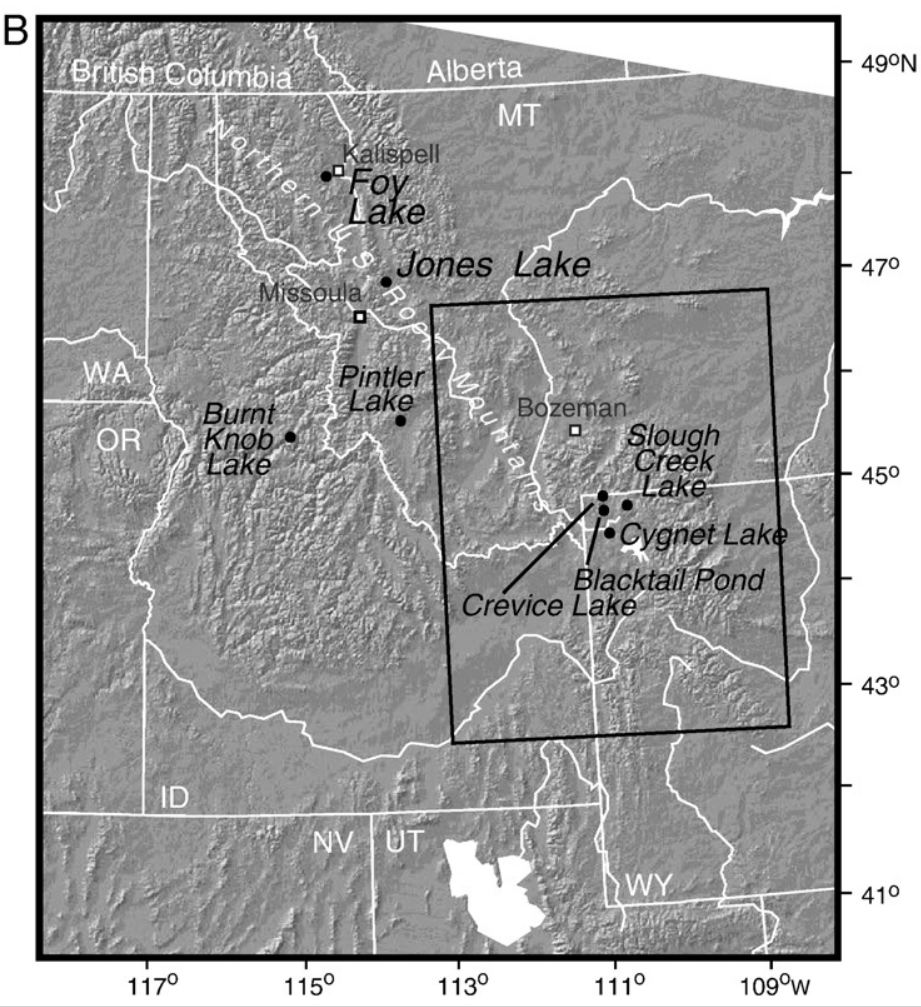

$\mathrm{D}$
C

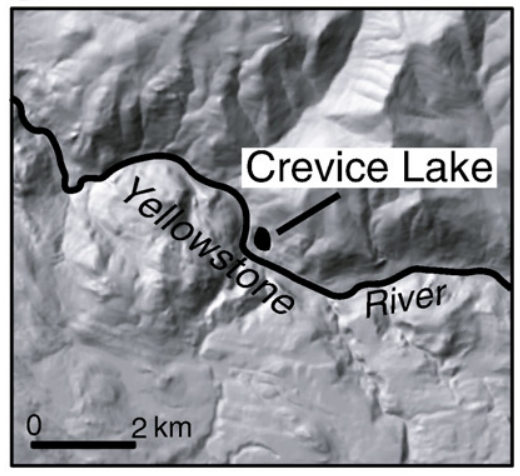

\section{D}

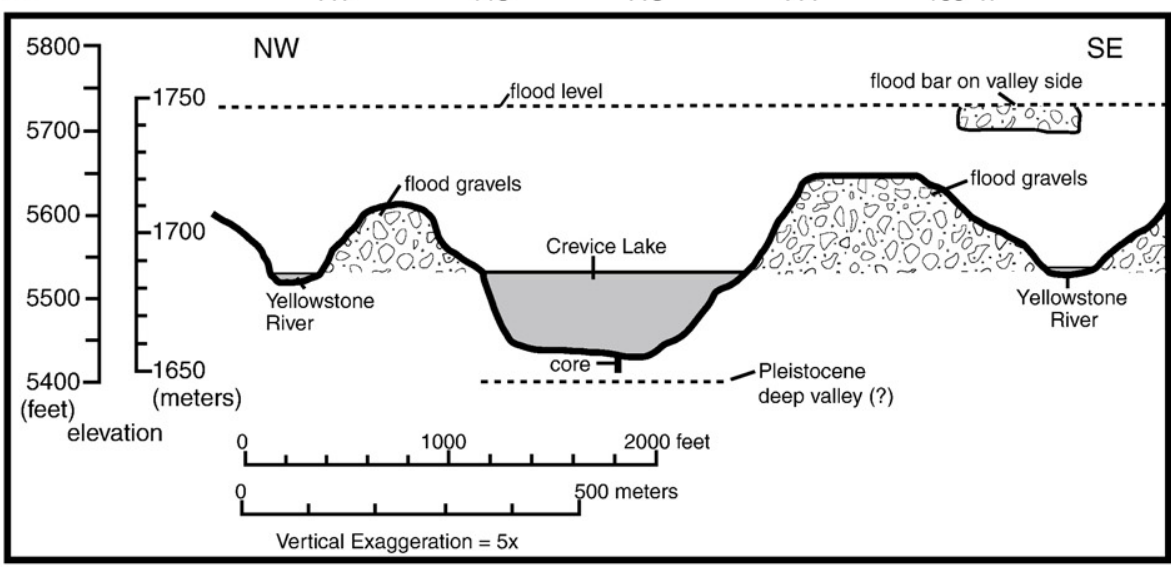

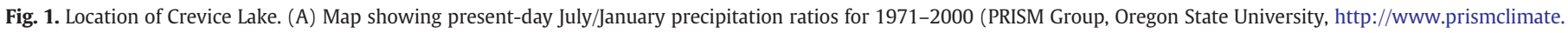

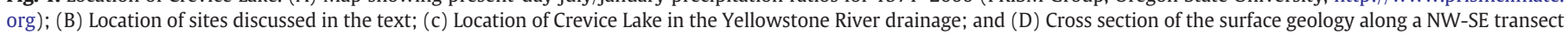
through Crevice Lake. 
matrix are attributed to glacial outburst floods during ice recession (Pierce, 1973). The base level of this flooding at $1750 \mathrm{~m}$ is shown in Fig. 1D. Deposits associated with these floods, $16 \mathrm{~km}$ down valley, are dated at $13.4 \pm 1.2{ }^{10} \mathrm{Be}$ ka (Pierce, 1979; Licciardi and Pierce, 2008), which is likely a maximum age for Crevice Lake as well. The lake resides in a buried channel of the Yellowstone River (of unknown age), and the steep-sided conical depression that holds Crevice Lake formed either from a late-glacial flood vortex (whirlpool) at a change in direction of the Black Canyon or from a residual block of ice (kettle) that escaped flood activity. Presently, the lake is separated from the Yellowstone River by permeable flood gravels that extend more than $30 \mathrm{~m}$ above the river and probably extend well below the river (Fig. 1D).

GPS surveys indicate that the Yellowstone River and Crevice Lake are at about the same elevation of $1684 \mathrm{~m}$ (C. Jaworowski, NPS Yellowstone, personal communication, 2010). The similarity in surface elevation suggests direct ground water exchange (Stevens and Dean, 2008) (Fig. 1). Jones et al. (1977) reported very little seasonal fluctuation of water level $(<26 \mathrm{~cm})$ in Crevice Lake; specific conductance $(620 \mu \mathrm{S})$ and alkalinity $(240 \mathrm{mg} / \mathrm{L})$ were high compared with other lakes in YNP. These factors and the intervening permeable flood sediment suggest a ground-water connection between the Yellowstone River and Crevice Lake that affects water level and chemistry.

The limited surface area (7.76 ha), conical bathymetry, and deep water $(>31 \mathrm{~m}$ ) of Crevice Lake create oxygen-deficient conditions in the hypolimnion that restrict bioturbation and preserve annually laminated sediment (varves) (Stevens and Dean, 2008; Whitlock et al., 2008). At present, Crevice Lake is a sodium-magnesiumbicarbonate lake (National Park Service, 1994), and the top of the thermocline during summer months is at a depth of approximately 5-6 m. Water-column profiles taken in July and August 2008 show that dissolved oxygen (DO) decreased from $11.3 \mathrm{mg} / \mathrm{L}$ at the surface to $2.4 \mathrm{mg} / \mathrm{L}$ below $15 \mathrm{~m}$ water depth. The presence of some oxygen $(<2 \mathrm{mg} / \mathrm{L})$ in the hypolimnion suggests that the lake turns over seasonally and that preservation of varves is related to the creation of an anoxic hypolimnion during the late summer. However, the hypolimnion may have been permanently anoxic (monimolimnion of the meromictic lake) below a depth of about 15 to $25 \mathrm{~m}$ in the past. However, diatoms and other algae would only be affected by stratification in the mixolimnion and cycling of nutrients from below 5-6 $\mathrm{m}$.

The closest weather station is in Mammoth (Yellowstone National Park), $10 \mathrm{~km}$ west of Crevice Lake, and measurements there extend back to 1894 (http://www.wrcc.dri.edu/cgi-bin/cliMAIN.pl?wy9905). Mean temperatures range from $-6.78{ }^{\circ} \mathrm{C}$ in January to $17.44{ }^{\circ} \mathrm{C}$ in July and $4.5^{\circ} \mathrm{C}$ annually. Annual precipitation is $39.4 \mathrm{~cm}$, and over the last 50 years, between 32 and $39 \%$ is received between April and June. The average summer/winter (JJA/DJF) moisture is 1.69 , as a result of low winter precipitation (e.g., January average $=0.45 \mathrm{~cm}$ ) and frequent summer convectional storms (July average $=0.53 \mathrm{~cm}$ ). The high summer/winter precipitation ratio qualifies the lake as a summer-wet site (sensu Whitlock and Bartlein, 1993).

The drainage basin currently supports open forests of Pseudotsuga menziesii (Douglas-fir), Juniperus scopulorum (Rocky Mountain juniper), and Pinus flexilis (limber pine), as well as steppe dominated by Artemisia tridentata (big sagebrush) and bunchgrasses. Pinus contorta (lodgepole pine) grows primarily on rhyolite substrates and above $2000 \mathrm{~m}$ elevation. Picea engelmannii (Engelmann spruce), Abies lasiocarpa (subalpine fir), and Pinus albicaulis (whitebark pine) are abundant at higher elevations (2400-2900 m) and in cold-air drainages. A rocky scree slope is present along the northern side of the watershed, but most of the catchment is vegetated. Betula occidentalis (water birch), Alnus incana (Rocky Mountain alder), and Salix (willow spp.) grow in moist settings in the Black Canyon of the Yellowstone River, and Carex (sedge), Scirpus (bulrush), and Typha latifolia (cattail) are present along the lake margin.

\section{Methods}

Sediments from the deepest part of lake were cored from the ice in February 2001 with a modified square-rod Livingstone piston corer, a larger diameter $(8-\mathrm{cm})$ UWITECH ${ }^{\circledR}$ percussion piston corer, and a freeze-box corer. Four overlapping UWITECH® cores were retrieved, split longitudinally, and photographed. The photographs were used to document sample locations, macrofossil locations, and general sedimentary changes, and to correlate among cores based on distinctive laminations. All sampling was done on sediments recovered by the freeze-box core and UWITECH® cores. Livingstone cores were used for correlation and archival purposes.

A composite section from the overlapping cores was $770 \mathrm{~cm}$ long (Rosenbaum et al., 2009) and designated "CV01". Sediments from 375 to 770 centimeters below lake floor ( $\mathrm{cmblf}$ ) were composed of massive calcite sand interbedded with laminated calcite mud and a 120 -cm-thick interval of jumbled angular blocks of laminated and massive carbonate. The massive units consisted of coarse- to finegrained calcite sand and mud, with seeds of Betula glandulosa, fragments of the green alga Chara, insect and chironomid remains, and angular shell fragments. These massive units likely represent one or a combination of slumps, turbidites, and debris flows on the steep sides of the lake, which brought sections of carbonate benches from the littoral zone to the center of the basin. The uncertain chronology and likely disconformities implied by the massive carbonate units led us to focus our analyses on the sediments above $375 \mathrm{cmblf}$.

Whitlock et al. (2008), Bracht et al. (2008), and Stevens and Dean (2008) describe analysis of magnetic properties, geochemistry, diatoms, pollen, and charcoal for last 2650 cal years (the interval above 112 cmblf). Both halves of the UWITECH ${ }^{\circledR}$ cores below $112 \mathrm{cmblf}$ were cut into $0.5-\mathrm{cm}$ slices to a depth of $470 \mathrm{cmblf}$. Every sample was analyzed for magnetic properties, and every eighth sample (every $4 \mathrm{~cm}$ ) was analyzed for geochemistry, mineralogy, and diatom species composition, with an average sample spacing of $80 \mathrm{yr}$. Pollen samples (0.5-cm-thick slices) below $112 \mathrm{cmblf}$ were spaced at intervals ranging from $2-10 \mathrm{~cm}$, and charcoal was analyzed in contiguous $0.5 \mathrm{~cm}$ samples for the entire length of the composite core.

The chronology for the Crevice Lake sediments was based largely on varve counts above $112 \mathrm{cmblf}$ and accelerator mass spectrometer (AMS) radiocarbon ages below that depth. In all, twenty-one age determinations were obtained, fifteen from terrestrial plant macrofossils and six from pollen concentrates (Table 1). The pollen concentrates consisted of the plant residue remaining after standard pollenpreparation procedures (Faegri et al., 1989), including charcoal, organic detritus, and pollen. Graphite targets were prepared in the USGS ${ }^{14} \mathrm{C}$ laboratory in Reston, Virginia and analyzed at the Center for Accelerator Mass Spectrometry (CAMS) at Lawrence Livermore National Laboratory in Livermore, California. Radiocarbon ages were calibrated using the terrestrial calibration data set with the CALIB 5.0.2 program (Stuiver et al., 1998) and the University of Cologne's online radiocarbon calibration program CalPal (http://www.calpal. de). A piece of wood in laminated calcite mud at $727.45 \mathrm{cmblf}$ was dated at 13,186 cal yr BP and is the oldest date from unquestionable profundal sediment. All ages are expressed in calendar years before present (cal yr BP), where present is AD 1950.

Concentrations of total carbon (TC) and total inorganic carbon (TIC) were determined by coulometric titration of $\mathrm{CO}_{2}$ following extraction from the sediment by combustion at $950{ }^{\circ} \mathrm{C}$ and acid volatilization, respectively (Engleman et al., 1985), in USGS laboratories, Denver, CO. Weight percent TIC was converted to weight percent $\mathrm{CaCO}_{3}$ by dividing the fraction of carbon in $\mathrm{CaCO}_{3}$ by 0.12 . Total organic carbon (TOC) was determined as the difference between TC and TIC. Organic matter (OM) content was assumed to be twice the TOC content (Dean, 1999). The accuracy and precision for both TC and TIC, determined from hundreds of replicate standards (reagent-grade $\mathrm{CaCO}_{3}$ and a Cretaceous OC-rich marlstone), was better than 0.10 weight $\%$. 
Table 1

Radiocarbon and calibrated ages from CV01 at Crevice Lake.

\begin{tabular}{|c|c|c|c|c|c|c|c|}
\hline \multirow[t]{2}{*}{ Sample ID } & Core & USGS radiocarbon & Material & Depth & Age AMS ${ }^{14} \mathrm{C}$ & CALIB Age & CalPal Age \\
\hline & Segment & Lab number & Dated & (cmblf) & (yr BP) & (cal. yr BP) & (cal. yr BP) \\
\hline CV-25 & CV01A-1 & WW-4618 & needle & 20.45 & $210 \pm 55$ & 190 & $185 \pm 114$ \\
\hline CV-108/109 & CV01A-1 & WW-4619 & needle & 49.45 & $1010 \pm 55$ & 900 & $908 \pm 66$ \\
\hline CV-148 & CV01A-1 & WW-4625 & needle & 63.30 & $1610 \pm 120$ & 1529 & $1534 \pm 132$ \\
\hline CV-184 & CV01A-1 & WW-4626 & needle & 75.85 & $1920 \pm 120$ & 1855 & $1871 \pm 143$ \\
\hline CV-213 & CV01A-1 & WW-4620 & bark & 83.85 & $2390 \pm 45$ & 2428 & $2484 \pm 111$ \\
\hline CV-272 & CV01A-1 & WW-4621 & needle & 104.15 & $2500 \pm 80$ & 2552 & $2569 \pm 126$ \\
\hline CV01A-1 88 & CV01A-1 & WW-5788 & plant frag. & 122.05 & $2878 \pm 33$ & 3007 & $3013 \pm 49$ \\
\hline CV-M4 & CV01C-2 & WW-4623 & wood & 255.20 & $5850 \pm 45$ & 6646 & $6663 \pm 61$ \\
\hline CV-M2 & CV01C-2 & WW-4627 & needle & 281.70 & $6340 \pm 250$ & 7176 & $7190 \pm 260$ \\
\hline Mazama & & & ash & 313.40 & & 7627 & 7627 \\
\hline CV-M1 & CV01C-2 & WW-4622 & needle & 340.90 & $7510 \pm 120$ & 8346 & $8309 \pm 107$ \\
\hline CV01B-2 45.5 & CV01B-2 & WW-5790 & plant frag. & 405.45 & $9145 \pm 67$ & 10327 & $10337 \pm 80$ \\
\hline CV01E-1 103 & CV01E-1 & CV01 E-1 103-104 & wood & 727.45 & $11300 \pm 52$ & 13186 & $13198 \pm 100$ \\
\hline
\end{tabular}

Twenty-two samples from above $180 \mathrm{cmblf}(<5000 \mathrm{cal}$ yr BP) were analyzed for total nitrogen (TN) in Huffman Laboratories, Golden, Colorado.

Samples were analyzed for 50 major, minor, and trace elements by inductively coupled plasma-mass spectrometry (ICP-MS) at SGS Laboratories, Toronto, Canada. Rock standards (USGS) were included with the sediment samples, and $5 \%$ of the samples were analyzed in duplicate. The precision, determined by analyzing rock standards and duplicate sediment samples, was better than $10 \%$ and usually better than $5 \%$ at a concentration of 10 times the limit of detection.

Semi-quantitative estimates of mineral contents were determined by standard X-ray diffraction (XRD) techniques (Moore and Reynolds, 1997) in USGS laboratories, Denver, CO. Results were reported as the peak intensity (in counts per second, cps) of the main XRD peak for each mineral and as a percentage of the sum of the main XRD peak intensities of all minerals. Percentage calculations are used with caution, because they do not reflect the different X-ray mass absorption characteristics of different minerals.

Stable-isotope values of endogenic calcite were determined at the University of Minnesota on a Finnigan-MAT 252 isotope-ratio massspectrometer coupled to a Kiel autosampling device. Samples were pre-treated for $12 \mathrm{~h}$ with $2 \%$ reagent-grade bleach to remove organic matter and then sieved at $63 \mu \mathrm{m}$ to remove ostracodes and shell material. The flow-through material $(<63 \mu \mathrm{m})$ was freeze-dried, crushed, and analyzed. Both $\delta^{18} \mathrm{O}$ and $\delta^{13} \mathrm{C}$ values are reported in the standard per mil (\%o), $\delta$-notation relative to the Vienna Pee Dee Belemnite (VPDB) marine-carbonate standard for carbon and oxygen.

Samples for diatom analysis (366 total) were treated with cold $10 \%$ hydrochloric acid and $30 \%$ hydrogen peroxide to remove carbonates and organic matter, respectively (Bracht et al., 2008). Samples were rinsed with reverse-osmosis purified water, dried onto coverslips, and mounted on slides with Zrax, a high- refractive-index permanent mounting medium. At least 300 individuals were identified and counted in each sample. Diatom counts are expressed as percentages relative to the total number of individuals counted in each sample.

A total of 103 pollen samples were prepared using standard procedures (Bennett and Willis, 2001), except that dilute Schulz solution was used instead of acetolysis treatment (Doher, 1980). Lycopodium spores were added to enable calculation of pollen concentration. Between 300-1000 pollen grains were counted for each level, and pollen percentages were based on the sum of terrestrial pollen and spores. Diploxylon-type Pinus pollen was attributed to $P$. contorta, and haploxylon-type Pinus was assigned to P. flexilis, which grows locally, but $P$. albicaulis from higher elevations in YNP also may have been a pollen source. Total Pinus was the sum of the diploxylon-type, haploxylon-type, and Undifferentiated Pinus pollen. The arboreal/nonarboreal ratio (AP/NAP), derived from the percentage of non-riparian tree pollen divided by that of shrubs and herbs, was used as an index of forest cover relative to steppe cover (Whitlock, 1993).

A total of 781 macroscopic charcoal samples, ranging between 0.5 and $1.0 \mathrm{~cm}^{3}$ in volume, were analyzed to reconstruct the local fire history. Samples were boiled for $15 \mathrm{~min}$ in $5 \%$ solution of potassium hydroxide and washed through a $125 \mu \mathrm{m}$ mesh sieve. The residues were examined at 36× magnification, and charcoal particles tallied. Charcoal counts were converted to concentration (particles $\mathrm{cm}^{-3}$ ) and then to charcoal accumulation rates (CHAR, particles $\mathrm{cm}^{-2} \mathrm{yr}^{-1}$ ) at constant time steps (12 years). The CHAR data were decomposed into a slowly varying background (BCHAR) component, using a Lowess smoother robust to outliers with a 500-year window width (http://CharAnalysis.googlepages.com; Higuera et al., 2010). BCHAR represents the long-term variations in fuel biomass, and charcoal peaks, which represent individual fire episodes, where the positive deviations (CHAR-BCHAR) that exceeded the 95th percentile distribution of a Gaussian mixture model. Peaks identification was based on 500-year overlapping window of the CHAR time series, producing a unique or "local" threshold for identifying fire episodes. Further screening eliminated those peaks or episodes that resulted from statistically insignificant variations in CHAR (Gavin et al., 2006). If the maximum count in a CHAR peak had a $>5 \%$ chance of coming from the same Poisson-distribution population as the minimum charcoal count within the preceding 75 years, then the fire episode was rejected (Higuera et al., 2010).

\section{Results}

\subsection{Chronology}

The age model consists of two parts: (1) a third-degree polynomial for the upper $112 \mathrm{~cm}$, which was derived in previous studies (Stevens and Dean, 2008; Whitlock et al., 2008); and (2) a linear model for the remainder of the record (Fig. 2). The linear model for the lower part of the section was constrained by the oldest two radiocarbon ages used in the previous studies, five additional radiocarbon ages from macrofossils, and the 7630-year-old Mazama ash (Zdanowicz et al., 1999). Radiocarbon dates from a bark fragment from a depth of $\sim 144$ cmblf (Table 1; Fig. 2) yielded an age that was deemed too old and rejected. Because of probable discontinuities in deposition, indicated by the massive blocks mentioned above that prompted us to restrict our analyses to sediments above 375 cmblf, most ages from below 375 cmblf were not incorporated in the model. However, one date from a plant fragment in laminated sediment from 405 cmblf was incorporated in the agedepth model (Table 1). No macrofossils were found between 144 and $255 \mathrm{cmblf}$, and ages were obtained from pollen concentrates to fill this gap. The pollen concentrates, however, yielded ages that were systematically older than those from macrofossils and the 

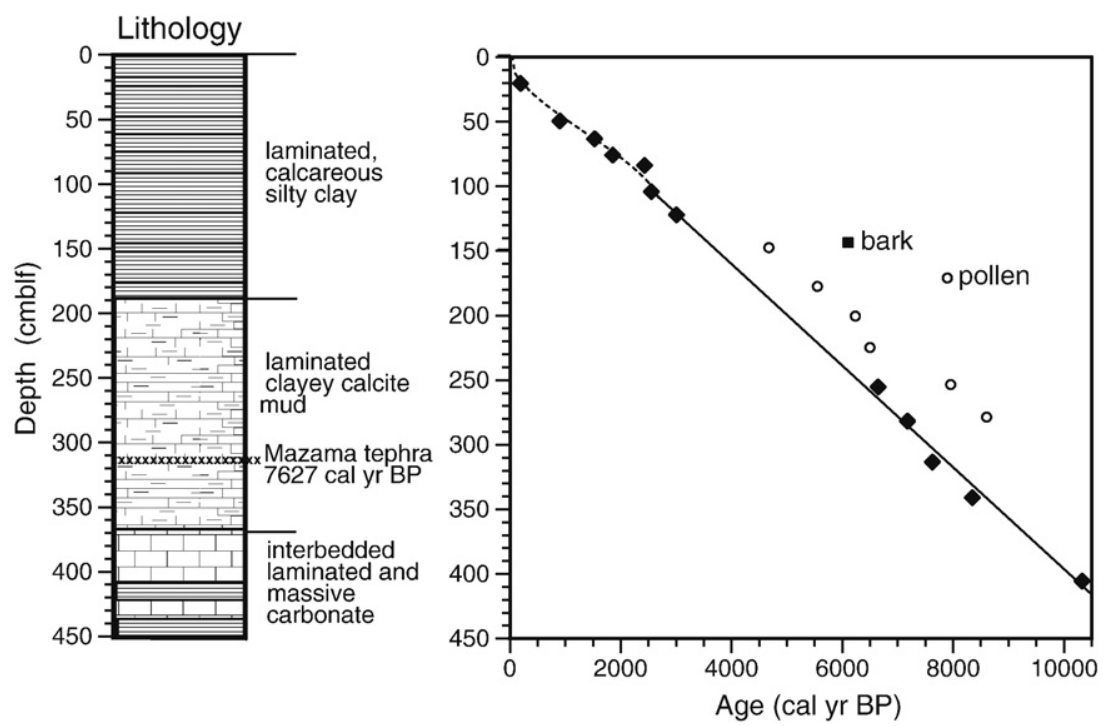

Fig. 2. Lithology and age-depth model for Crevice Lake core CV01based on AMS radiocarbon dates (Table 1).

Mazama ash (Table 1; Fig. 2), and they too were not used in the age-depth model.

\subsection{Lithology, geochemistry, and mineralogy}

Following the sediment classification of Schnurrenberger et al. (2003), we use the term "mud" with appropriate modifiers to describe fine-grained calcareous sediment; for example, fine-grained sediment containing $>30 \% \mathrm{CaCO}_{3}$ is "clayey calcite mud". Fine-grained sediments dominated by aluminosilicate material are referred to as "silty clay" or "clayey silt". The sediments recovered above $375 \mathrm{cmblf}$ ( $<9400$ cal yr BP) appeared to be conformable, continuous, and composed of laminated calcareous silty clay $\left(<30 \% \mathrm{CaCO}_{3}\right)$ and laminated clayey calcite mud $\left(>30 \% \mathrm{CaCO}_{3}\right.$ ) (Fig. 2 ), with laminae that ranged in thickness from 0.3 to $0.7 \mathrm{~mm}$. These sediments settled seasonally from surface waters into the profundal zone to form light-dark varve couplets.

Sediments deposited in the last 9400 cal years consist of fourcomponents: detrital clastic material (aluminosilicates) in the form of silt and clay, endogenic $\mathrm{CaCO}_{3}$ as calcite, organic matter, and biopal (biogenic opal) from diatom remains. A record of detrital influx into the lake is provided by elemental chemistry and X-ray diffraction (XRD) mineralogy (Fig. 3). Most detrital material was composed of quartz with minor amounts of feldspar (Fig. 3). Aluminum (Al) and titanium (Ti) were used as measures of detrital input, because their concentrations are largely unaffected by weathering and postdepositional alteration. With the exception of several spikes, $\mathrm{Al}$ and Ti content after 9400 cal yr BP varied by a factor of $<2 \%$ and averaged about 1.71 and $0.078 \%$, respectively (Fig. 3). Approximate amounts of quartz and feldspar increased from averages of 18 and 6\% between 9400 and $5000 \mathrm{cal} \mathrm{yr}$ BP to averages of 29 and $12 \%$ after $5000 \mathrm{cal} \mathrm{yr}$ $\mathrm{BP}$, with amounts increasing towards present (Fig. 3). Assuming that the rock debris in Crevice Lake sediments has the elemental composition of average continental crust (7.8\% Al and $0.42 \% \mathrm{Ti}$ ), sediments deposited after 9400 cal yr BP contained about 22\% detrital clastic material on average.

Like other $\mathrm{CaCO}_{3}$-rich lakes, Crevice Lake presumably creates a carbon pump in which the $\mathrm{CaCO}_{3}$ content in sediments results from the amount produced in the surface waters and the amount dissolved in the bottom waters and sediments. In general, high levels of $\mathrm{CaCO}_{3}$ indicate warm surface waters and high $\mathrm{CaCO}_{3}$ production, providing dissolution is low. Sediments deposited between 9400 and 5000 cal yr BP contained an average of $37 \% \mathrm{CaCO}_{3}$ as calcite, whereas sediments deposited after 5000 cal yr BP averaged 11\% (Fig. 3). The lower contents of $\mathrm{CaCO}_{3}$ in sediments deposited after 5000 cal yr BP is mainly due to dilution by detrital clastic material as indicated by the high contents of quartz and feldspar (Fig. 2). The very low values of $\mathrm{CaCO}_{3}$ in sediments deposited between 2000 and 1300 cal yr BP is likely caused by extreme dilution and corresponds to extremely high feldspar contents (Fig. 3), although some might be related to the dissolution of carbonate (Stevens and Dean, 2008). The high concentrations of easily decomposed feldspar, relative to weather-resistant quartz, indicate that the glacial flood deposits, the likely source of most of the detrital material, were rapidly deposited and unweathered. The amount of calcite shows a similar decrease upward, but values were higher than $\% \mathrm{CaCO}_{3}$, because bulk XRD calcite data overestimates the actual amount of $\mathrm{CaCO}_{3}$. As indicated in the Methods section, XRD percentages should be used with caution, because they do not take into account the different X-ray mass-absorption characteristics of different minerals. Both detrital and $\mathrm{CaCO}_{3}$ components were diluted by biopal, which composed $50 \%$ of the sediment after 5000 cal yr BP (Fig. 3).

Total organic carbon (TOC) increased from an average of $5.7 \%$ in sediments before $5000 \mathrm{cal} \mathrm{yr}$ BP to an average of $9.9 \%$ after 5000 cal yr BP (Fig. 3). Organic matter (OM) content, which typically is about twice the TOC content (Dean, 1999), was $11 \%$ on average in sediments deposited between 9400 and $5000 \mathrm{cal} \mathrm{yr} \mathrm{BP}$ and increased to $20 \%$ in sediments deposited after 5000 cal yr BP. Biopal abundance is a reflection of diatom productivity, relative to the other components in the sediments. Average biopal content, calculated as the difference between $100 \%$ and the sum of the percentages of the three other sedimentary components, was 26\% between 9400 and $5000 \mathrm{cal} \mathrm{yr} \mathrm{BP}$ and $50 \%$ in sediments after that. The average sediment younger than 5000 cal yr BP was classified as an organic-rich, calcareous, diatomaceous silty clay, or simply a calcareous diatomite (Whitlock et al., 2008).

Twenty-two samples from sediments younger than 5000 cal yr BP were analyzed for total nitrogen (TN). Aquatic vegetation and algae have low $\mathrm{C} / \mathrm{N}$ ratios, typically between 4 and 10 , whereas vascular land plants, which contain cellulose, have $\mathrm{C} / \mathrm{N}$ ratios $>20$ (Meyers and Teranes, 2001). The TOC/TN ratio in sediments younger than 5000 cal yr BP averaged 11.8 and showed no temporal variation, suggesting the organic matter was predominantly autochthonous. This ratio matched those from surface sediments of 13 lakes in YNP (average of 10.5; $n=65$ ) (Dean, 2006). The high biopal in the sediments, especially after $5000 \mathrm{cal}$ yr BP, is further evidence for the autochthonous origin of the sedimentary organic matter. 


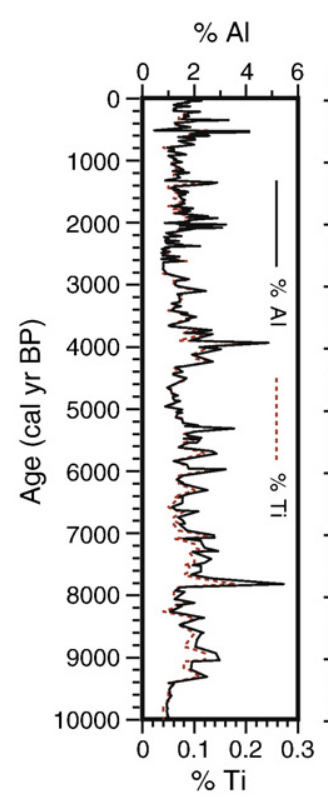

$$
\% \mathrm{CaCO}_{3}
$$

$\%$ TOC
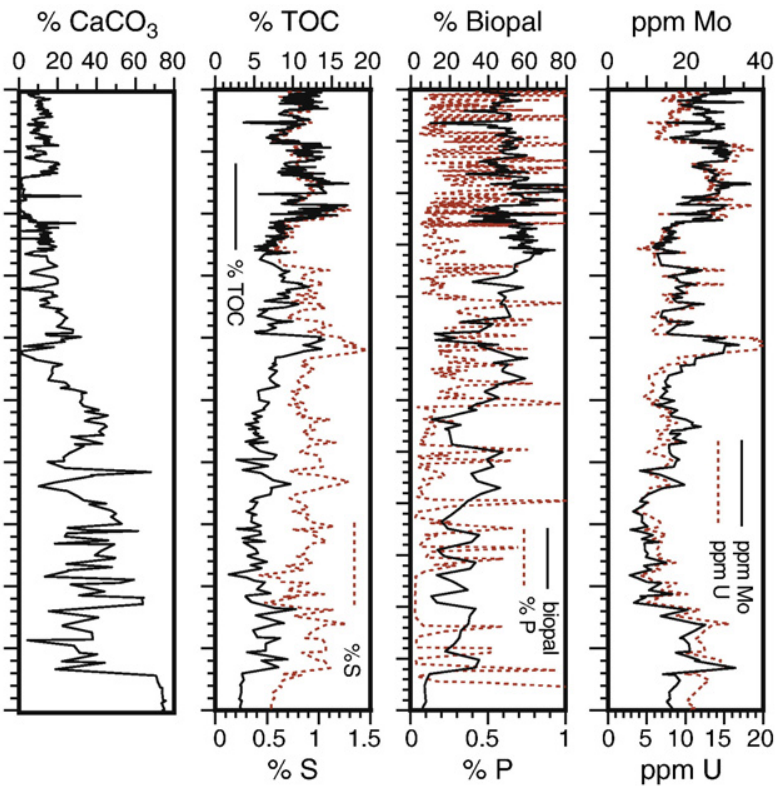

$\%$ Calcite

$\%$ Quartz

$\%$ Feldspar

$\delta^{18} \mathrm{O}$
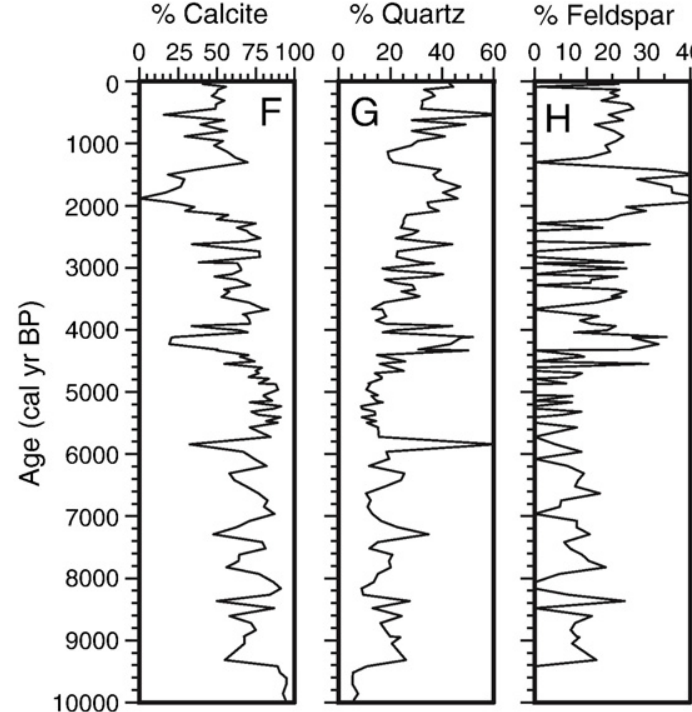

(o/oo VPDB)

$\delta^{13} \mathrm{C}$

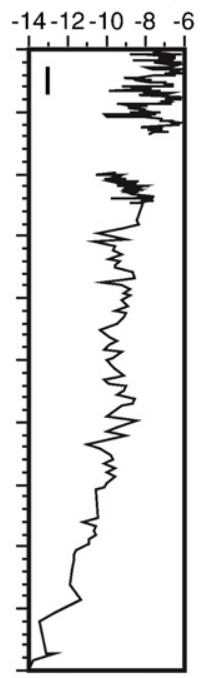

(o/oo VPDB)

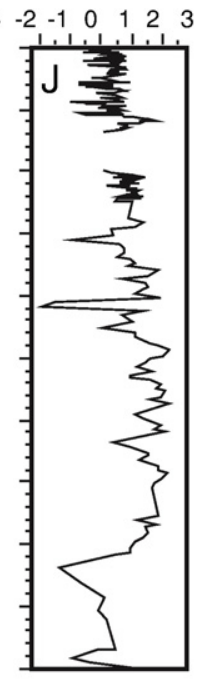

Fig. 3. Concentrations (percent or parts per million) of selected elements, percentages of selected minerals; and values of $\delta^{18} \mathrm{O}$ and $\delta^{13} \mathrm{C}$ in core CV01 from Crevice Lake.

Certain elements, including uranium (U), vanadium (V), nickel $(\mathrm{Ni})$, zinc $(\mathrm{Zn})$, cadmium $(\mathrm{Cd})$ and molybdenum $(\mathrm{Mo})$, are concentrated in TOC-rich sediments deposited under oxygen-deficient conditions where sulfate reduction has occurred (Jacobs et al., 1985; Emerson and Huested, 1991; Piper and Dean, 2002). Thus, intervals where these elements are abundant in the sediments imply periods of oxygen deficiency in the hypolimnion of Crevice Lake. The concentration of sulfate in surface waters of Crevice Lake is high $(87 \mathrm{mg} / \mathrm{L})$, which indicates that bottom waters support bacterial sulfate reduction. Concentrations of $U$ and Mo in the Crevice Lake sediments were positively correlated with each other and with sulfur (S) and TOC (Fig. 3), but also with V, Zn, Cd, arsenic (As), and selenium (Se) (not shown; $r>0.5$ and mostly $>0.7$ ). This covariance is most obvious in sediments deposited before 5000 cal yr BP. Variations in the concentrations of these elements reflect changing redox conditions, with higher concentrations of S, U, and Mo reflecting strongly reducing environments and oxygen-deficient, sulfidic bottom water, driven by the decomposition of high concentrations of produced organic matter. Because concentrations of these elements are relatively high throughout the sedimentary record, it is likely that the bottom waters were anoxic at least by late summer throughout most of the lake's history; before $8200 \mathrm{cal} \mathrm{yr} \mathrm{BP,} \mathrm{between} 4400$ and $4000 \mathrm{cal} \mathrm{yr} \mathrm{BP}$, and after 2200 cal yr BP, bottom waters were probable anoxic yearround (meromictic). Thus, the varved sediments indicate either permanently or seasonally anoxic bottom water.

\subsection{Stable isotopes}

Previous work at Crevice Lake indicates a clear link between the amount of discharge of the Yellowstone River and the $\delta^{18} \mathrm{O}$ values of Crevice Lake carbonates on decadal time scales (Stevens and Dean, 2008). This link was attributed to snowpack run-off in the Yellowstone River drainage and transference of the river water $\delta^{18} \mathrm{O}$ signature to the lake via ground water. Low $\delta^{18} \mathrm{O}$ values are attributed to wet winters with high snowpack, leading to higher discharge of ${ }^{18} \mathrm{O}$-depleted groundwater.

Values of $\delta^{18} \mathrm{O}$ for the last 9400 cal years ranged from $-14 \%$ 。 to $-6 \%$. Centennial-scale oscillations and step-like changes were superimposed on an overall trend of increasing values. Before $9000 \mathrm{cal}$ yr BP, values of $\delta^{18} \mathrm{O}$ values were strongly negative $(-14 \%)$ 
but increased to $-10 \%$ by $7000 \mathrm{cal} \mathrm{yr}$ BP (Fig. 3). Values averaged $-9.4 \%$ o between 7000 and 2400 cal yr BP and showed no temporal trend (Fig. 3), which indicates stability within the lake and/or the hydroclimatic system. A decline in $\delta^{18} \mathrm{O}$ values occurred from 2650 to $2000 \mathrm{cal} \mathrm{yr} \mathrm{BP}$, and the absence of calcite in the sediment between 2000 and 1400 cal yr BP resulted in a gap in the isotopic record. After $1400 \mathrm{cal}$ yr BP, $\delta^{18} \mathrm{O}$ values were the highest of the record, with an average of $-7.3 \%$ o (Fig. 3 ).

We recognize that interpreting the $\delta^{18} \mathrm{O}$ variations in terms of winter snowpack is contrary to most isotopic interpretations from authigenic carbonates, which infer ${ }^{18} \mathrm{O}$ enrichment as related to warmer source regions, summer precipitation, and/or higher evapotranspiration (Anderson, 2011). However, it is the unique setting of Crevice Lake and its groundwater connection with the Yellowstone River that allows the opportunity to examine winter conditions. Modern values of $\delta^{18} \mathrm{O}$ in Yellowstone Lake increase from about $-20 \%$ at the inlet to about $-16 \%$ in the outlet as a result of evaporation (VSMOW; Balistrieri et al., 2007), and this magnitude of difference from evaporation is insufficient to explain the Crevice Lake trends. An alternative source of variation, beyond standard considerations (e.g., moisture source and pathway, altitude of condensation, and dewpoint temperature) might be from Holocene fluctuations in surface area and residence time in the headwater Yellowstone Lake. Yellowstone Lake shoreline reconstructions suggest that lake levels were above present prior to 8000 cal yr BP, fell to below-present levels by $3000 \mathrm{cal}$ yr BP, and then rose again in the last 3000 cal years to modern levels (Pierce et al., 2007). These large-scale fluctuations do not match well with the gradual $\delta^{18} \mathrm{O}$ enrichment observed at Crevice Lake, and an explanation that links surface area and resident time in Yellowstone Lake to the Crevice Lake $\delta^{18} \mathrm{O}$ variations is not strongly supported. Furthermore, changes in geothermal inputs are also unlikely to account for the variations in $\delta^{18} \mathrm{O}$, because geothermal features are absent in the Crevice Lake watershed, and there is currently no evidence of long-term trends in geothermal activity in the region. Thus, the Crevice Lake record is inferred to be a signal of primarily winter precipitation and secondarily to increased evaporation.
Values of $\delta^{13} \mathrm{C}$ of organic carbon (OC) in YNP lake sediments likely reflect productivity (removal of ${ }^{12} \mathrm{C}$ by phytoplankton) and hydrology (residence time), rather than contributions from terrestrial sources as indicated by the low $\mathrm{C} / \mathrm{N}$ ratios. A longer residence time allows more exchange between the surface waters and the atmosphere, enriching DIC in ${ }^{13} \mathrm{C}$. For most of the Holocene, $\delta{ }^{13} \mathrm{C}$ values ranged between 0 and $+2 \%$ (Fig. 3). Values of $\delta^{13} \mathrm{C}$ decreased between 8600 and 8300 cal yr BP, from $0 \%$ o to less than $-1 \%$, then increased to $1 \%$ at $8000 \mathrm{cal} \mathrm{yr}$ BP. Between 7500 and $4200 \mathrm{cal} \mathrm{yr} \mathrm{BP}, \delta^{13} \mathrm{C}$ values were highest of any in the Holocene (average $+1.6 \%$ ), but also variable (Fig. 3). A notable 100-year long drop in $\delta{ }^{13} \mathrm{C}$ occurred at 4200 cal yr BP. After 3500 cal yr BP, values of $\delta^{13} \mathrm{C}$ decreased from 2 to $0 \%$, then increased to $1 \%$ at the base of the carbonate hiatus (2000 cal yr BP). After the carbonate hiatus ( $<1400$ cal yr BP), $\delta{ }^{13} \mathrm{C}$ values averaged $0.5 \%$.

\subsection{Diatoms}

Diatom assemblages alternated between Stephanodiscus and Synedra, genera characteristic of spring water-column mixing, and Cyclotella species that bloom during times of stable summer stratification (Interlandi et al., 1999). Stephanodiscus and Synedra tenera dominated prior to 2200 cal yr BP (Fig. 4) and during much of the last $800 \mathrm{yr}$ (Bracht et al., 2008). S. minutulus and to a lesser extent S. medius were abundant, except between 5600 and 5200 cal yr BP and 2000 and $800 \mathrm{cal}$ yr BP. Synedra tenera was present in low percentages prior to $7200 \mathrm{cal} \mathrm{yr} \mathrm{BP}$, and values generally increased to a maximum at $2500 \mathrm{cal} \mathrm{yr}$ BP. After $2000 \mathrm{cal}$ yr BP, it was present intermittently in low values. In the Yellowstone region, Stephanodiscus species (S. minutulus, S. medius) flourish during isothermal mixing in the spring, when phosphorus is regenerated from the hypolimnion and mixed throughout the water column (e.g., Bradbury and DiderichRurup, 1993). Synedra tenera also blooms during spring or early summer but expands in abundance when phosphorus concentrations are low, following the nutrient depletion of surface waters that occurs after the spring Stephanodiscus diatom bloom. Thus, the co-dominance

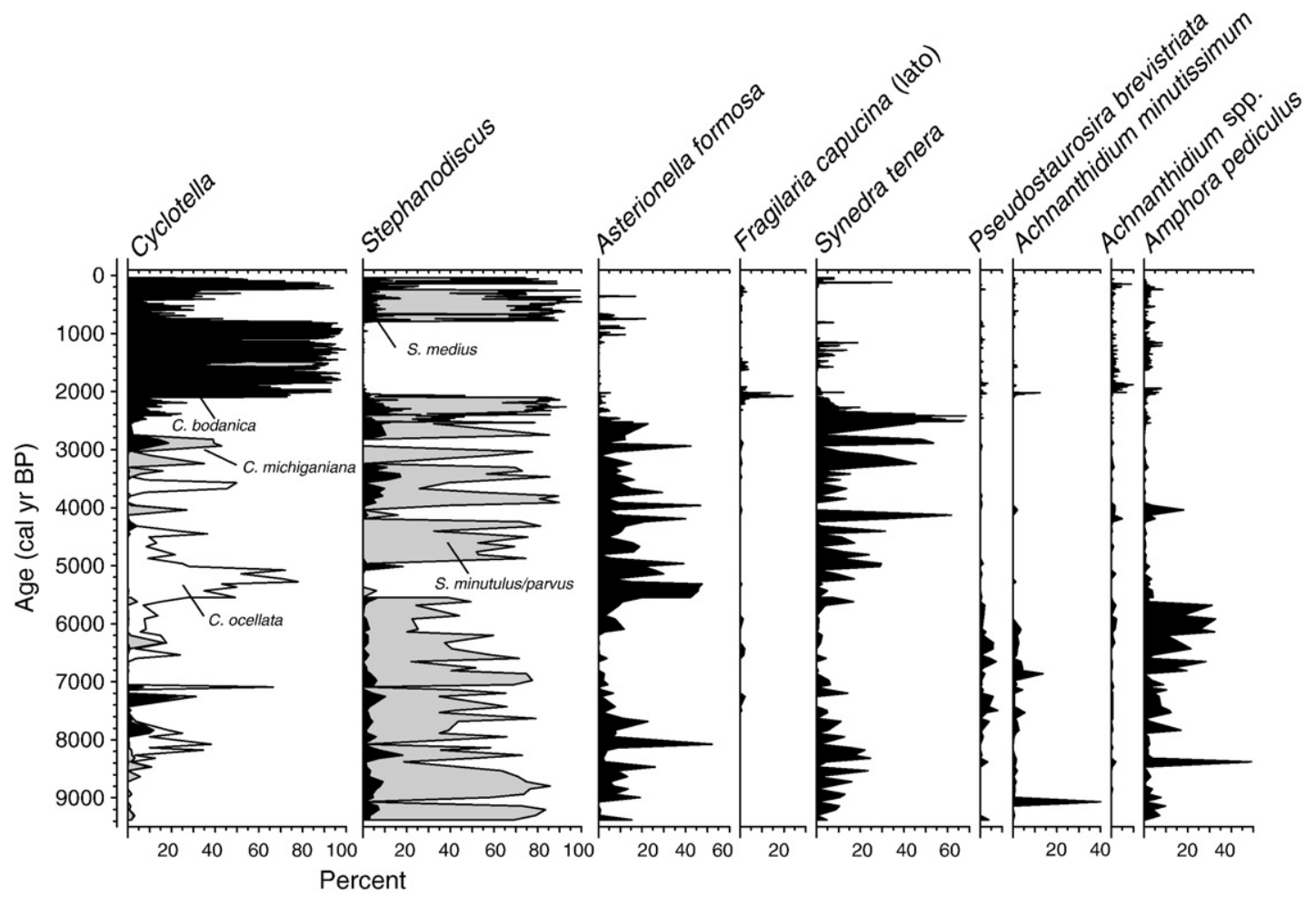

Fig. 4. Percentages of selected diatom taxa in core CV01 from Crevice Lake. 
of Stephanodiscus and Synedra during much of the last 9400 cal yr indicates an extended period of mixing of the water column during spring.

Cyclotella species (C. bodanica, C. michiganiana, C. ocellata) are characteristic of high nitrogen and low phosphorus surface waters, and these species in the Yellowstone region are often found near the thermocline in summer, when lakes are thermally stratified (J. Saros and Stone, unpublished data, 2010). High-elevation lakes on the nearby Beartooth Plateau suggest that depth of the mixed surface layer and hence the stability of thermal stratification influences Cyclotella distribution, with $C$. ocellata representing the most shallow summer mixing depth, $C$. bodanica the deepest mixing depth, and C. michiganiana an intermediate between the two (J. Stone unpublished data). Thus, the species likely represent a gradient of summer conditions from warm conditions (i.e., C. ocellata and C. michiganiana indicate a shallow water-column mixing and thermocline depth) to cool conditions (i.e., C. bodanica indicates a deep thermocline and water-column mixing).

In the Crevice Lake record, $C$. ocellata had intermediate percentages between 8600 and $7600 \mathrm{cal} \mathrm{yr}$ BP and high values between 6200 and $4300 \mathrm{cal}$ yr BP. C. michiganiana was present in low values until $4200 \mathrm{cal} \mathrm{yr}$ BP and reached high percentages between 2000 and 800 cal yr BP. C. bodanica was nearly absent before 3000 cal yr BP, reached high percentages between 2200 and $800 \mathrm{cal}$ yr BP, dropped to low values between 800 and 300 cal yr BP, and then increased in the last 300 years.

\subsection{Pollen and charcoal}

The pollen record reveals significant trade-offs in conifer and grassland taxa over the last $9400 \mathrm{cal}$ yr BP that suggest shifts in forest density and composition. Prior to 8200 cal yr BP, Pinus pollen dominates and the identifiable Pinus grains were equally weighted between Pinus flexilis-type (haploxlon) and Pinus contorta-type (diploxylon). Juniperus pollen was abundant (up to 11\%) before 8200 cal yr BP, which suggests an important role for J. scopulorum or possibly the shrub J. communis (common juniper). In contrast, Poaceae, Chenopodiaceae, and other herbaceous pollen types were poorly represented ( $<5 \%$ each) prior to $8200 \mathrm{cal}$ yr BP. Extensive forest cover is indicated by the relatively high AP/NAP ratio $(>4)$ before 8300 cal yr BP. Unlike modern forests near Crevice Lake, however, the early Holocene vegetation featured more Pinus flexilis (and/or P. albicaulis) and Juniperus. Fire activity during this time was variable, with mean fire frequencies of 2-8 episodes $\mathrm{kyr}^{-1}$ (i.e., fire return intervals of 125-425 years) and a single large fire-episode (i.e., abundant particles $\mathrm{cm}^{-2}$ peak ${ }^{-1}$ ) at 9150 cal yr BP (Fig. 5).

From 8200 to 2800 cal yr BP, percentages of Pseudotsuga-type (from $2-7 \%$ ), Poaceae ( $>5 \%$ ), Artemisia (>15\%), and Chenopodiaceae ( $>3 \%$ after $8847 \mathrm{cal}$ yr BP) increased, and Pinus, particularly Pinus flexilis-type $(<10 \%)$, and Juniperus pollen (mostly $<5 \%$ ) decreased (Fig. 5). The low AP/NAP ratio (1-3) also suggests less forest cover than before or at present. This shift in the pollen assemblage marks the initial appearance of open Douglas-fir woodland in the region, suggesting effectively drier conditions during the growing season than before (Whitlock, 1993). After $6000 \mathrm{cal} \mathrm{yr} \mathrm{BP,} \mathrm{Picea} \mathrm{and} \mathrm{Abies}$ pollen were present in low percentages $(<3 \%)$, marking the expansion of mesophytic forest in local areas of cold air drainage and at higher elevations (Whitlock, 1993). Fire frequency increased to more than 5 episodes $\mathrm{kyr}^{-1}$ by $8000 \mathrm{cal}$ yr BP and to ten fire episodes $\mathrm{kyr}^{-1}$ in the next two millennia. The rise of Juniperus-type pollen between 6000 and 2000 cal yr BP suggests further expansion of xerophytic forest near Crevice Lake. Large-magnitude fire episodes at 5554, 3981 and 3591 cal yr BP were not matched by changes in pollen, which suggests small local fire events, probably limited by fuel availability, rather than large-area burns. The increase in CHAR at the top of the record suggests more severe or large fire episodes in the last $600 \mathrm{cal}$ years.

\section{Discussion}

The Crevice Lake datasets indicate changes in watershed characteristics, hydrology and biota during the history of the lake, including variations in vegetation, fire regime, limnobiota, surface watercolumn stratification, bottom-water oxygen, and carbonate precipitation (Fig. 6). We compare the findings at Crevice Lake with other sites in YNP to evaluate whether the reconstructed climate history is consistent with the summer-wet/summer- dry hypothesis (Whitlock and Bartlein, 1993). Our comparison sites include Blacktail Pond $(\mathrm{JJA} / \mathrm{DJF}=1.49), 6 \mathrm{~km}$ southwest of Crevice Lake and $300 \mathrm{~m}$ higher (Huerta et al., 2009); Slough Creek Lake (JJA/DJF=1.87), $20 \mathrm{~km}$ southeast of Crevice and $200 \mathrm{~m}$ higher (Whitlock and Bartlein, 1993; Millspaugh et al., 2004); and Cygnet Lake (JJA/DJF=0.83), a summer-dry site $37 \mathrm{~km}$ south and $800 \mathrm{~m}$ higher in central YNP (Fig. 1). We also discuss the Yellowstone results in light of other high-resolution multi-proxy records in the northern Rocky Mountain region, most notably data from Jones Lake (a summer-wet site: JJA/ $\mathrm{DJF}=1.75$ ) in the Ovando Valley of northwestern Montana, $188 \mathrm{~km}$ northwest of Crevice Lake (Shapley et al., 2009) and Foy Lake (a drier summer-wet site, JJA/DJF=1.22) in the Salish Mountains of the Flathead River Basin, about $470 \mathrm{~km}$ northwest of Crevice Lake (Stevens et al., 2006; Stone and Fritz, 2006; Shuman et al., 2009; Power et al., 2011) (Fig. 1). We draw on recent regional syntheses of the Holocene environmental history in the northern Rocky Mountains (Whitlock and Brunelle, 2006; Whitlock et al., 2008; Shuman et al., 2009; Power et al., 2011) and note that Crevice Lake contributes new information by clarifying the nature of seasonal variations in climate during the last $9400 \mathrm{cal} \mathrm{yr} \mathrm{BP.}$

\subsection{Early Holocene (9400-8000 cal yr BP)}

Paleoclimate simulations suggest that the early Holocene climate in the western U.S. was governed by the direct and indirect influences of stronger-than-present summer and annual insolation and lowerthan-present winter insolation (Fig. 6) (Bartlein et al., 1998). An additional component of early Holocene perihelion that is not often mentioned is the fact that the summer season (JJA) was 4-5 days shorter than at present, and thus higher summer insolation levels were concentrated in a shortened season (Berger, 1978). As noted previously, the amplification of the modeled seasonal cycle of insolation led to warmer temperatures and indirectly strengthened the northeastern Pacific subtropical high-pressure systems, as well as summer monsoonal circulation, between 12,000 and $6000 \mathrm{cal}$ yr BP. Increased winter precipitation in the early Holocene may be a result of diverted storm tracks by the lingering ice sheet (Williams et al., 2010) and lowerthan-present winter insolation at that time (Bartlein et al., 1998).

The Crevice Lake record shows responses that are consistent with insolation-driven increases in summer temperature, decreases in winter temperatures, and more winter storms. The high AP/NAP pollen ratio and abundance of Pinus (including high levels of $P$. flexilis and/or P. albicaulis) prior to 8200 cal yr BP indicate a closed forest, which requires abundant moisture during the growing season. Blacktail Pond and Slough Creek Lake in northern YNP also indicate closed forests of Pinus, Picea, Juniperus, and Betula at this time. The charcoal record indicates low fire-episode frequency and high fuel-biomass levels at all three sites in northern YNP, which suggests large standreplacing events at widely spaced intervals. This fire regime is typical of pine and spruce forests in YNP at present (Baker, 2009).

Prior to 8200 cal yr BP, Crevice Lake bottom waters were strongly oxygen deficient and sulfidic, as evidenced by high concentrations of Mo, S, and $\mathrm{U}$. These conditions were driven by decomposition of elevated concentrations of organic matter (average TOC $=6.7 \%$; Fig. 3 ). Production of $\mathrm{CaCO}_{3}$ was very high prior to $9400 \mathrm{cal}$ yr BP (up to $80 \%$ ) and somewhat lower afterwards, although generally $>40 \%$ until 5000 cal yr BP. High concentrations of $\mathrm{CaCO}_{3}$ in early Holocene 


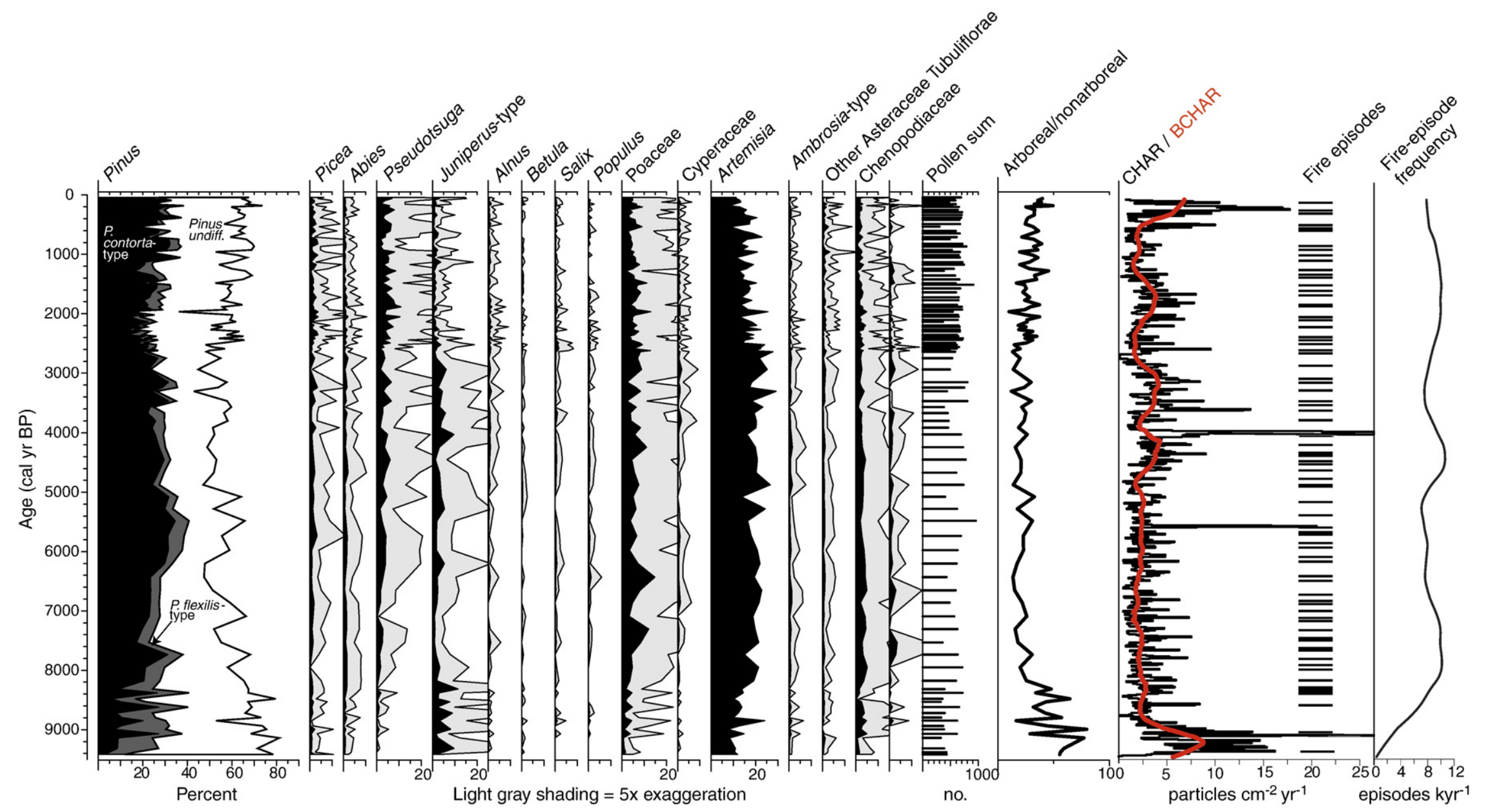




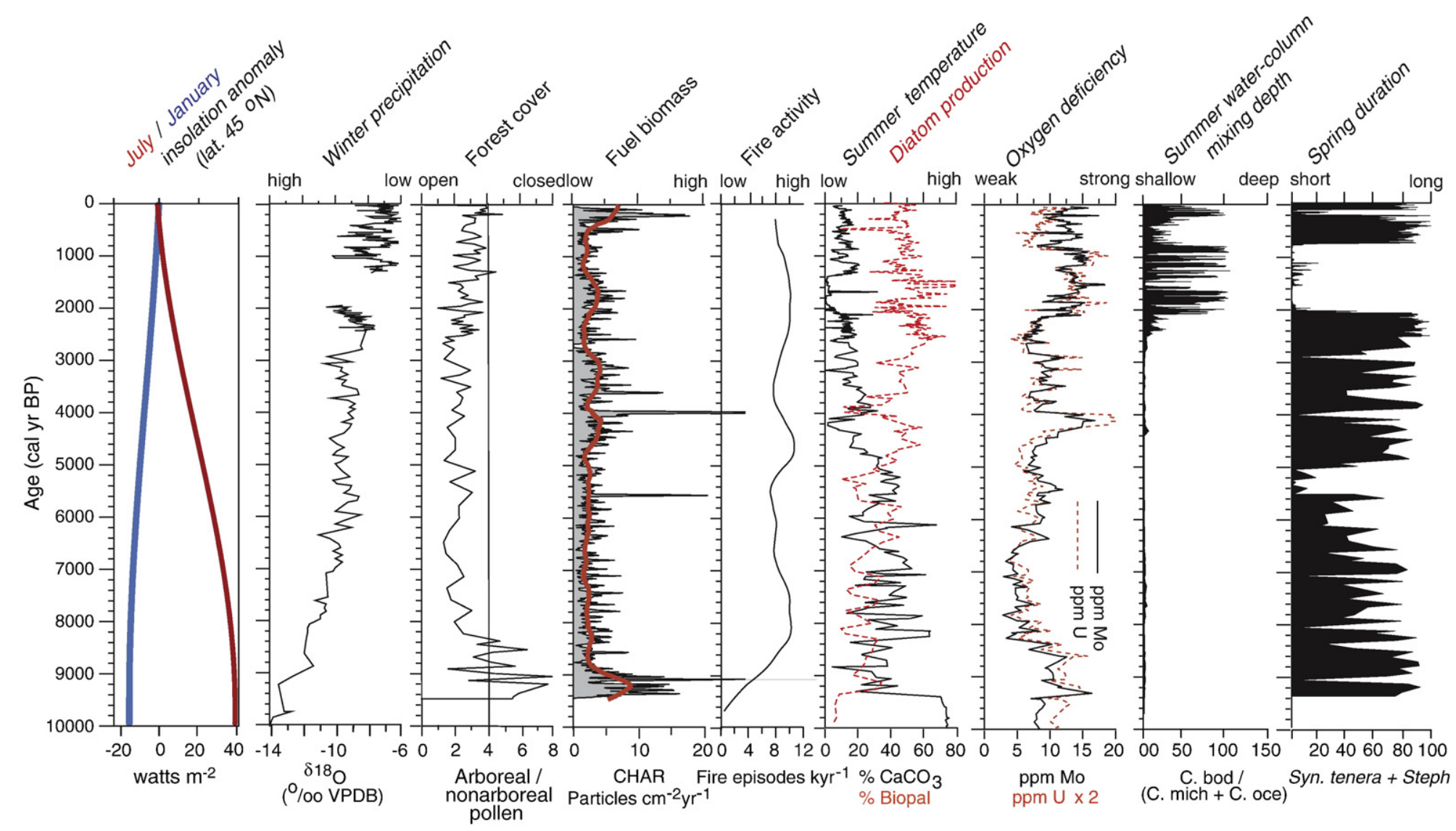

Fig. 6. Summary of the environmental proxy at Crevice Lake over the last 9400 cal yr BP plotted against July and January insolation anomalies. 
sediments (average of 34.5\%; Fig. 6) suggests warm surface waters that likely resulted from the short but intense summers, possibly aided by an initial pulse of dissolved $\mathrm{CaCO}_{3}$ from calcareous glacial drift.

Diatom productivity (biopal) was low in the early Holocene (Fig. 6), and the dominance of Stephanodiscus, which would sequester $\mathrm{P}$ recycled into the water column, explains the low $\mathrm{P}$ concentrations in the sediments at this time (Fig. 3). Cyclotella species were present, except between 8600 and $7800 \mathrm{cal} \mathrm{yr}$ BP, and the dominance of C. ocellata over other Cyclotella species implies strong thermal stratification of the epilimnion during summer and shallow mixing depths (Fig. 6). Low values of $\delta^{18} \mathrm{O}$ prior to $8200 \mathrm{cal}$ yr BP (Fig. 3) indicate abundant winter precipitation at higher elevations, which influenced the $\delta^{18} \mathrm{O}$ content of the Yellowstone River and its ground water connection with Crevice Lake. The low values could also be evidence of low summer evapotranspiration, as result of a shortened season or greater cloudiness. Low $\delta^{13} \mathrm{C}$ values between 10,000 and $8000 \mathrm{cal} \mathrm{yr}$ $\mathrm{BP}$ do not match variations in carbonate or biopal, which argues against productivity as the explanation. A sharp decrease in $\delta^{13} \mathrm{C}$ values between 8800 and 8200 cal yr BP is not reflected in the $\delta^{18} \mathrm{O}$ data (Fig. 3), suggesting that changes in residence time are not the cause of the decline. The values, however, do correspond with an increase in the AP/NAP pollen ratio, which implies that $\delta^{13} \mathrm{C}$ values may be controlled by carbon inputs from forest soils rather than from aquatic sources.

Taken together, the early Holocene of northern YNP was characterized by abundant snowfall, forested vegetation, infrequent but large fire events, high freshwater carbonate production and oxygendeficient bottom waters. These interpretations, in turn, are consistent with cool winters, protracted springs, and warm but effectively wet summers. The carryover of moisture from winter into spring and early summer was likely responsible for greater forest cover (inferred from the pollen data) and the increased fuel load would have resulted in infrequent but severe fires (inferred from the charcoal data). High summer temperatures during the summer insolation maximum led to greater carbonate production, a shallow summer thermocline, and anoxic conditions (inferred from the geochemical and diatom data). Summer precipitation, if enhanced, may have contributed to the infrequency of fires.

Other paleoenvironmental data from the northern Rocky Mountain region suggest early-Holocene conditions that were warmer than at present, although effective moisture levels at this time were higher than in the middle Holocene (Whitlock and Brunelle, 2006; Power et al., 2011; Whitlock et al., 2011). For example, pollen records from high-elevation sites indicate an upslope expansion of low-elevation taxa in the northern Rocky Mountains (e.g., Pseudotsuga and Chenopodiaceae) in the early Holocene (Whitlock and Brunelle, 2006) and those from low-elevation sites show relatively open forest conditions (Power et al., 2011; Whitlock et al., 2011). Warm humid summer conditions in the early Holocene are broadly registered throughout the Rockies and Great Plains (e.g., Fall, 1997; Shuman et al., 2010; Williams et al., 2010; Anderson, 2011; Grimm et al., 2011; Jiménez-Moreno et al., 2011; Minckley et al., 2011; Whitlock et al., 2011; Briles et al., 2012) and ascribed to higher-than-present summer insolation and its attendant effects on regional climate.

Charcoal data indicate rising fire occurrence (Whitlock et al., 2008, 2011; Power et al., 2011), which is attributed to rising summer temperatures and decreased effective moisture. At Foy Lake, extended periods dominated by benthic diatom species with high salinity tolerances as well as high levels of diatom frustule dissolution indicate lower-than-present water levels (Stone and Fritz, 2006; Shuman et al., 2009). Oxygen-isotope and carbonate mineralogy data from lowelevation Jones Lake also indicate warm dry conditions with little ground-water recharge in the early Holocene (Shapley et al., 2009). In northwestern Colorado, early Holocene $\delta^{18} \mathrm{O}$ values from sediment cores study at Bison Lake (3255 m elevation) indicate rain-dominated precipitation, suggestive of warmer winters and protracted springs, and lower-than-present lake levels (Shuman et al., 2009; Anderson, 2011).

\subsection{Middle Holocene (8000-3000 cal yr BP)}

The middle Holocene was characterized by declining summer insolation and rising winter insolation (Fig. 6). Paleoclimate model simulations suggest a weakening of the subtropical high-pressure system and summer monsoonal circulation, as well as slightly warmer winters (Bartlein et al., 1998). At Crevice Lake, Blacktail Pond, and Slough Creek Lake, lower AP/NAP values and higher Poaceae pollen percentages indicate the development of open parkland and effectively drier summers than before or at present. Pseudostuga percentages increased steadily from 8000 cal yr BP to the present, marking its expansion at lower treeline (Fig. 5). At Crevice Lake and Blacktail Pond, fire activity was high between 8000 and 7000 cal yr BP, fell slightly between 7000 and 5000 cal yr BP, and rose between 5000 and $4000 \mathrm{cal}$ yr BP. Slough Creek Lake shows a general trend toward more fires in the middle Holocene (Millspaugh et al., 2004), and Cygnet Lake, a summer-dry site in central YNP, registered highest fire frequency before $6000 \mathrm{cal}$ yr BP followed by steadily decreasing activity to the present day (Whitlock, 1993).

Concentrations of TOC, Mo, U, and S at Crevice Lake were low between 8000 and $4500 \mathrm{cal} \mathrm{yr}$ BP, which indicates better-oxygenated bottom waters and perhaps only seasonal anoxia as a result of lower organic productivity. High production of $\mathrm{CaCO}_{3}$ suggests warm surface waters until about $5000 \mathrm{cal}$ yr BP. After $4500 \mathrm{cal} \mathrm{yr}$ BP, increased concentrations of Mo, $\mathrm{U}$, and $\mathrm{S}$ indicate strongly oxygen-deficient (probably anoxic) bottom-waters, and rising TOC and biopal percentages indicate increased diatom production (Fig. 6). Values of $\delta^{18} \mathrm{O}$ rose to $-10 \%$ by 5800 cal yr BP and imply less snow accumulation and/or enhanced evaporation in summer. These values persist with little change until 3000 cal yr BP. Prolonged spring conditions through the middle Holocene are inferred from abundant Stephanodiscus and Synedra tenera (Fig. 4). The absence of Stephanodiscus and low abundance of Synedra between ca. 5600 and 5000 cal yr BP suggest that spring conditions were shorter in that interval. The increase in Cyclotella ocellata and rise in $\mathrm{CaCO}_{3}$ at this time indicate shallow water-column mixing and strong summer stratification, consistent with warm summers and seasonal anoxia. Thus, the Crevice data imply that winters were drier than before, spring conditions were prolonged, and summers were warm although cooling. A period of very short springs leading into warm dry summers occurred between 5600 and $5000 \mathrm{cal} \mathrm{yr}$ BP.

The transition to more open vegetation in Yellowstone after 8000 cal years broadly coincides with maximum aridity at many locations in the Rocky Mountains and mid-continent (e.g., see Bartlein and Whitlock, 1993; Whitlock and Brunelle, 2006; Williams et al., 2009; Shuman et al., 2010; Grimm et al., 2011). In the northern Rocky Mountains, well-developed grassland and open parkland, high fire activity, and low lake levels characterized low elevations (MacDonald, 1989; Brunelle et al., 2005; Stone and Fritz, 2006; Shuman et al., 2009; Power et al., 2011; Whitlock et al., 2011). The Rocky Mountain pattern is an interesting contrast to records from the Pacific Northwest, which register cooler effectively wetter conditions after 7000 cal yr BP (Whitlock and Brunelle, 2006; Barron and Anderson, 2011).

The diatom assemblage at Foy Lake alternated between periods dominated by Cyclotella michiganiana, which indicate strong summer stratification at intermediate water depths, and periods with benthic and tychoplankton species, which suggest low lake levels. Episodes of reduced moisture occurred between 8000 and 7000 cal yr BP, very dry conditions between 7000 and $5600 \mathrm{cal} \mathrm{yr}$ BP, and dry conditions with some wet intervals between 5600 and 3500 cal yr BP (Stone and Fritz, 2006). At Jones Lake, high aragonite/calcite ratios and 
$\delta^{18} \mathrm{O}$ values before 5600 cal yr BP are also consistent with higherthan-present aridity during the middle Holocene. Lake levels from northwestern Montana to southern Colorado were lower in the early part of the middle Holocene, and widespread aridity then is explained as a combination of drier winters and greater evaporative demand in summers (Shuman et al., 2009). Lake levels began to rise after $5500 \mathrm{cal}$ yr BP, suggesting the onset of effectively winter conditions and/or cooler summers. In Wyoming, this event coincides with evidence of high water levels from 5600 to 4800 cal yr BP (Minckley et al., 2011).

\subsection{Late Holocene (ca. 3000 cal yr BP-present)}

The decreasing amplitude of the seasonal cycle of insolation in the late Holocene led to the establishment of the modern climate and vegetation (Whitlock and Brunelle, 2006). At Crevice Lake, expansion of Pseudotsuga and Pinus and decline of Juniperus suggest cooler growing-season conditions than before. Fuel biomass (based on BCHAR) was high between 4500 and $1600 \mathrm{cal} \mathrm{yr} \mathrm{BP,} \mathrm{low} \mathrm{between}$ 1600 and 300 cal yr BP, and high in the last 300 cal years. Fire episodes at Crevice and Slough Creek lakes were large but infrequent in the last 300 cal yr BP.

High $\delta^{18} \mathrm{O}$ values during the late Holocene indicate lower winter precipitation compared with earlier conditions, but intervals of somewhat wetter winters are inferred by declines in $\delta^{18} \mathrm{O}$ between 2200 and 2000, 1100 and 800, and 500 and 400 cal yr BP. Low $\mathrm{CaCO}_{3}$ levels in the last 3000 cal yr BP suggest cool summers, and production of $\mathrm{CaCO}_{3}$ between 2200 and $1400 \mathrm{cal}$ yr BP was reduced. In addition, $\mathrm{CaCO}_{3}$ was diluted by the influx of detrital material indicated by increases in concentrations of quartz and feldspar. Replacement of Stephanodiscus by Cyclotella bodanica between 2200 and 800 cal yr BP marks a time when the spring season was shortened and the transition from winter to summer was rapid. The dominance of C. bodanica over other Cyclotella species indicates deep watercolumn mixing, i.e., the top of the thermocline was deep in summer at this time, and high concentrations of TOC, Mo, $\mathrm{U}$, and S indicate that bottom waters were permanently anoxic (meromictic) as a result of the decomposition of organic matter. Today, the top of the thermocline in late summer is about 5 or $6 \mathrm{~m}$. The lake is $>31 \mathrm{~m}$ deep and, if it was meromictic, the top of the anoxic monimolimnion would have been at $15-25 \mathrm{~m}$. Therefore, the mixolimnion would be stratified with a hypolimnion of 10-20 $\mathrm{m}$ if the top of the thermocline was at $5 \mathrm{~m}$, and that hypolimnion itself would be highly oxygen deficient by late summer as it is today (ca. $2 \mathrm{mg} / \mathrm{L}$ ).

The isotope, diatom, geochemistry, and charcoal evidence together indicate that winters became drier and summers cooler in the last 3000 cal years, with some dramatic excursions towards drier and/or wetter conditions. Abbreviated spring conditions, for example, characterized the Roman Warm Period (centered ca. 2000 cal yr BP) and the Medieval Climate Anomaly (between ca. 1200 and $800 \mathrm{cal} \mathrm{yr}$ $\mathrm{BP})$, and other records from the northern Rocky Mountains also show multiple decadal-long droughts at these times (Laird et al., 1996; Woodhouse and Overpeck, 1998; Fritz et al., 2001; Case and MacDonald, 2003; Pierce et al., 2004; Stevens et al., 2006; BrachtFlyr and Fritz, 2012). In northern YNP, summer aridity during the Medieval Climate Anomaly is evidenced by increased fire frequency at Slough Creek Lake (Millspaugh et al., 2004), fire-triggered sedimentation events (Meyer et al., 1995), reduced beaver activity (Persico and Meyer, 2009), and increases in dry-adapted rodents (Hadly, 1994).

A sharp decline of Cyclotella bodanica and return of Stephanodiscus at 800 cal yr BP coincide with the onset of the Little Ice Age and suggests lengthening spring conditions. Low concentrations of Mo and especially $U$ indicate better-oxygenated bottom waters after $800 \mathrm{cal} \mathrm{yr}$ BP and a loss of year-round anoxia. At $400 \mathrm{cal} \mathrm{yr} \mathrm{BP}$, an increase in $C$. bodanica and its co-occurrence with Stephanodiscus coincides with slight increases $\mathrm{CaCO}_{3}, \mathrm{TOC}, \mathrm{Mo}, \mathrm{U}$, and S. The combination suggests that springs were cool and wet, and summers were short but warm enough to lead to a deep thermocline, increased productivity, and seasonally anoxic bottom waters. Charcoal data also indicate a return to a stand-replacing fire regime, which is also consistent with spring fuel development followed by warm summers. Tree-ring-derived Palmer Drought Severity Index (PDSI) data for northern YNP indicate alternating wet and dry periods in the last 800 cal years, shifting to effectively wetter conditions towards the present (Cook et al., 2004). A tree-ring reconstruction from the Yellowstone region also indicates periods of moderate drought in recent centuries but nothing as extreme as during the Medieval Climate Anomaly (Gray et al., 2007). Thus, the last $400-600$ cal years can be considered intermediate in the range of conditions experienced in the Holocene.

\section{Conclusions}

Multiple proxy data from Crevice Lake and their comparison with other records in YNP and the northern Rocky Mountains permit a reevaluation of the summer-wet/summer-dry hypothesis (Whitlock and Bartlein, 1993). Consistent with the hypothesis and broad regional patterns, Crevice Lake and the northern YNP sites show evidence of warmer-than-present summers in the early Holocene as the climate shifted from cool glacial conditions to the Holocene thermal maximum. Higher-than-present summer temperatures are explained as a direct consequence of greater summer insolation compressed into a shortened summer season between 11,000 and $6000 \mathrm{cal} \mathrm{yr} \mathrm{BP.} \mathrm{Equal-}$ ly important, however, is evidence of wet conditions, which we explain as high winter and spring snowpack leading to greater effective moisture in summer. This interpretation is slightly different than the summer-wet/summer-dry hypothesis, which emphasizes increased summer precipitation from a strengthened monsoonal system to explain expanded forest and decreased fire frequency during the early Holocene. The Crevice Lake results thus suggest that carryover of winter moisture into the growing season likely accounted for effectively wet summers as much or more than moisture contributions from summer convective storms.

As winter snowpack decreased in the middle Holocene, the season of highest precipitation shifted to spring. Currently, dry winters followed by wet springs and summer moisture deficits are characteristic of severe fire years (Westerling et al., 2006), and high fire activity in the middle Holocene may also be explained by fine-fuel development during wet springs followed by summer drought. Summers were cooler and drier than before as a result of decreasing summer insolation, but still warmer than at present. The middle Holocene also featured considerable climate variability; however, the three highresolution records from the northern Rocky Mountains (Crevice, Foy, and Jones lakes) do not display concurrent patterns of drought on submillennial time scales. Our data agree with others that suggest that the period between 8000 and $4000 \mathrm{cal}$ yr BP was the driest interval of the Holocene in the Rocky Mountain region and Great Plains (Dean et al., 1996; Shinker et al., 2006; Shuman et al., 2009; Grimm et al., 2011; Whitlock et al., 2011). In YNP, for example, highest fire frequency is registered at so-called summer-wet and summer-dry sites.

Dramatic environmental variability occurred in the last $3000 \mathrm{cal}$ years, with repercussions to the terrestrial and limnologic ecosystems. The Crevice Lake data suggest initially wet winters, cool springs, and cool summers between 2600 and 2200 cal yr BP, followed by a period of extreme drought composed of dry winters, brief springs, and dry summers between 2200 and $800 \mathrm{cal} \mathrm{yr}$ BP. The last 400-600 cal years have featured intermediate conditions in which winters have been relatively dry, springs have been wet and sometimes lengthy, and summers are relatively dry.

It is worth noting that environmental changes of the last few centuries at Crevice Lake and other northern Rocky Mountain sites are 
relatively modest compared with what occurred earlier in the Holocene. Over the last 9400 cal years, climate variations on centennial and millennial time scales influenced the duration of winter snowpack and its carryover into spring and summer, with widespread ecological consequences. On shorter time scales, dramatic fluctuations in effective moisture during the middle and late Holocene led to rapid adjustments in limnological and terrestrial ecosystems at Crevice Lake and across the northern Rocky Mountains. Our results suggest that the historical range of seasonal variability evident in Yellowstone National Park during the Holocene can provide a useful context for evaluating recent and projected environmental changes.

\section{Acknowledgements}

We gratefully acknowledge the support of J. Varley and T. Olliff (Yellowstone Center for Resources, Yellowstone National Park) in providing funding and continued logistical support. Christy Briles assisted with age-model development. Field and coring assistance was provided by the YNP Fire Cache staff, L. Doner, J. Honke, G. Skipp. P. Bartlein provided Fig. 1A and insolation anomaly data on Fig. 6. D. McWethy and $\mathrm{L}$. Anderson provided helpful reviews of an earlier version of the manuscript, and we received two helpful anonymous reviews. Funds from the Global Change and Climate History and Earth Surface Dynamics Programs of the U.S. Geological Survey, the Canon Foundation, and National Science Foundation (EAR-0818467; OISE-0966472 to Whitlock; EAR-0816576 to Fritz; EAR-9905262 to Stevens and Fritz) supported this project.

\section{References}

Anderson, L., 2011. Holocene record of precipitation seasonality from lake calcite $\delta^{18} \mathrm{O}$ in the central Rocky Mountains, United States. Geology 39, 211-214.

Baker, W.L., 2009. Fire Ecology in Rocky Mountain Landscapes. Island Press, Washington DC. 605 pp.

Balistrieri, L.S., Shanks III, W.C., Cuhel, R.L., Aguilar, C., Klump, J.V., 2007. The influence of sublacustrine hydrothermal vent fluids on the geochemistry of Yellowstone Lake. In: Morgan, L.A. (Ed.), Integrated geoscience studies in the Greater Yellowstone Area; volcanic, tectonic, and hydrothermal processes in the Yellowstone Geoecosystem: U.S. Geological Survey Professional Paper, 1717, Chapter F, pp. 117-199.

Barron, J.A., Anderson, L., 2011. Enhanced Late Holocene ENSO/PDO expression along the margins of the eastern Pacific Margin. Quaternary International 235, 3-12.

Bartlein, P.J., Whitlock, C., 1993. Paleoclimatic interpretation of the Elk Lake pollen record. In: Bradbury, J.P., Dean, W.E. (Eds.), Evidence for rapid climate change in the North-Central, United States: The Elk Lake record: Geological Society of America Special Paper, 276, pp. 275-293.

Bartlein, P.., Anderson, P.M., Anderson, K.H., Edwards, M.E., Thompson, R.S., Webb, R.S., Webb III, T., Whitlock, C., 1998. Paleoclimate simulations for North America over the past 21,000 years: features of simulated climate and comparisons with paleoenvironmental data. Quaternary Science Reviews 17, 549-585.

Bennett, K.D., Willis, K.J., 2001. Pollen. In: Smol, J.P., Birks, H.J.B., Last, W.M. (Eds.), Tracking Environmental Change Using Lake Sediments. : Terrestrial, Algal, and Siliceous Indicators, Vol. 3. Kluwer Academic Publishers, Dordrecht, pp. 5-32.

Berger, A.L., 1978. Long-term variations of caloric insolation resulting from Earth's orbital elements. Quaternary Research 9, 139-167.

Bracht, B.B., Stone, J.R., Fritz, S.C., 2008. A diatom record of late Holocene climate variation in the northern range of Yellowstone National Park, USA. Quaternary International 188, 149-155.

Bracht-Flyr, B.B., Fritz, S.C., 2012. Synchronous climatic change inferred from diatom records in four western Montana lakes in the US Rocky Mountains. Quaternary Research. doi:10.1016/j.yqres2011.12.005.

Bradbury, J.P., Diderich-Rurup, S.K., 1993. Diatom paleolimmnology of Elk Lake, Minnesota. In: Bradbury, J.P., Dean, W.E. (Eds.), Elk Lake, Minnesota: Evidence for Rapid Climate Change in the North-Central United States: Boulder, Colorado, Geological Society of America Special Paper, 276, pp. 215-238.

Briles, C.E., Whitlock, C., Meltzer, D., 2012. Last glacial-interglacial environments in the southern Rocky Mountains, USA and implications for Younger Dryas-age human occupation. Quaternary Research 77, 96-103.

Brunelle, A., Whitlock, C., Bartlein, P.J., Kipfmuller, K., 2005. Postglacial fire, climate, and vegetation history along an environmental gradient in the Northern Rocky Mountains. Quaternary Science Reviews 24, 2281-2300.

Case, R.A., MacDonald, G.M., 2003. Tree-ring reconstructions of streamflow for three Canadian Prairie rivers. Journal of American Water Resources Association 38, 703-716.

Cook, E.R., Woodhouse, C.A., Eakin, C.M., Meko, D.M., Stahle, D.W., 2004. Long-term aridity changes in the western United States. Science 306, 1015-1018.
Dean, W.E., 1999. The carbon cycle and biogeochemical dynamics in lake sediments. Journal of Paleolimnology 21, 375-393.

Dean, W.E., 2006. Characterization of organic matter in lake sediments from Minnesota and Yellowstone National Park. U.S. Geological Survey Open-File Report 2006-1053. 40 pp. (http://pubs.usgs.gov/of/2006/1053).

Dean, W.E., Ahlbrandt, T.S., Anderson, R.Y., Bradbury, J.P., 1996. Regional aridity in North America during the middle Holocene. The Holocene 6, 145-155.

Doher, L.I., 1980. Palynomorph preparation procedures currently used in the paleontology and stratigraphy laboratories. United States Geological Survey Circular, 830. Washington, D.C.

Emerson, S.R., Huested, S.S., 1991. Ocean anoxia and concentrations of molybdenum and vanadium in seawater. Marine Chemistry 34, 177-196.

Engleman, E.E., Jackson, L.L, Norton, D.R., Fischer, A.G., 1985. Determination of carbonate carbon in geological materials by coulometric titration. Chemical Geology 53, 125-128.

Faegri, K., Kaland, P.E., Krzywinski, K., 1989. Textbook of Pollen Analysis, 4th Ed. Blackwell, New York. 340 pp.

Fall, P.L., 1997. Timberline fluctuations and late Quaternary paleoclimates in the Southern Rocky Mountains, Colorado. Geological Society of America Bulletin 109, 1306-1320.

Fritz, S.C., Metcalf, S.E., Dean, W.E., 2001. Holocene climate of the Americas inferred from paleolimnological records. In: Markgraf, V. (Ed.), Interhemispheric Climate Linkages (Present and past interhemispheric climate linkages in the Americas and their Societal effects). Academic Press, pp. 241-264.

Gavin, D.G., Hu, F.S., Lertzman, K., Corbett, P., 2006. Weak climatic control of standscale fire history during the late Holocene. Ecology 87, 1722-1732.

Gray, S.T., Betancourt, L.J., Graumlich, J.L., 2007. Annual precipitation in the Yellowstone National Park region since AD 1173. Quaternary Research 68, 18-27.

Grimm, E.C., Donovan, J.J., Brown, K.J., 2011. A high-resolution record of climate variability and landscape response from Kettle Lake, northern Great Plains, North America. Quaternary Science Reviews 30, 2626-2650.

Hadly, E., 1994. Influence of late-Holocene climate on northern Rocky Mountain mammals. Quaternary Research 46, 298-310.

Higuera, P.E., Gavin, D.G., Bartlein, P.J., Hallett, D.J., 2010. Peak detection in sedimentcharcoal records: impacts of alternative data analysis methods on fire-history interpretations. International Journal of Wildland Fire 19, 996-1014.

Huerta, M., Whitlock, C., Yale, J., 2009. Holocene Vegetation-fire-climate linkages in northern Yellowstone National Park, USA. Palaeogeography, Palaeoclimatology, Palaeoecology 271, 170-181.

Interlandi, S.J., Kilham, S.S., Theriot, E.C., 1999. Responses of phytoplankton to varied resource availability in large lakes of the Greater Yellowstone Ecosystem. Limnology and Oceanography 44, 668-682.

Jacobs, L., Emerson, S., Skei, J., 1985. Partitioning and transport of metals across the $\mathrm{O}_{2}$ / $\mathrm{H}_{2} \mathrm{~S}$ interface in a permanently anoxic basin, Framvaren Fjord, Norway. Geochimica et Cosmochimica Acta 49, 1433-1444

Jiménez-Moreno, G., Anderson, R.S., Atudorei, V., Toney, J.L., 2011. A high-resolution record of climate, vegetation, and fire in the mixed conifer forest of northern Colorado, USA. Geological Society of America Bulletin 123, 240-254.

Jones, R.D., Varley, J.D., Jennings, D.E., Rubrecht, S.M., Gresswell, R.E., 1977. Fishery and aquatic management program in Yellowstone National Park. U.S. Fish and Wildlife Service. Technical Report for 1976, Yellowstone National Park, Wyoming.

Laird, K.R., Fritz, S.C., Grimm, E.C., Mueller, P.C., 1996. Century-scale paleoclimatic reconstruction from Moon Lake, a closed-basin lake in the northern Great Plains. Limnology Oceanography 41, 890-902.

Licciardi, J.M., Pierce, K.L., 2008. Cosmogenic exposure-age chronologies of Pinedale and Bull Lake glaciations in greater Yellowstone and the Teton Range, USA. Quaternary Science Reviews 27, 814-831.

MacDonald, G.M., 1989. Postglacial paleoecology of the subalpine forest-grassland ecotone of southwestern Alberta: new insights on vegetation and climatic change in the Canadian Rocky Mountains and adjacent Foothills. Paleogeography, Paleoclimatology, Paleoecology 73, 155-173.

Meyer, G.A., Wells, S.G., Jull, A.J.T., 1995. Fire and alluvial chronology in Yellowstone National Park; climatic and intrinsic controls on Holocene geomorphic processes. Geological Society of America Bulletin 107, 1211-1230.

Meyers, P.A., Teranes, J.L., 2001. Sediment organic matter. In: Last, W.M., Smol, J.P. (Eds.), Tracking Environmental Change Using Lake Sediments, Vol. 2. Kluwer Academic Publishers, Dordrecht, pp. 239-269.

Millspaugh, S.H., Whitlock, C., Bartlein, P., 2004. Postglacial fire, vegetation, and climate history of the Yellowstone-Lamar and Central Plateau provinces, Yellowstone National Park. In: Wallace, L. (Ed.), After the Fires: The Ecology of Change in Yellowstone National Park. Yale University Press, New Haven, pp. 10-28.

Minckley, T.A., Shriver, R.K., Shuman, B.N., 2011. Resilience and regime change in southern Rocky Mountain ecosystem during the past 17000 years. Ecological Monographs. doi:10.1890/11-0283.1.

Mock, C.J., 1996. Climatic controls and spatial variations of precipitation in the western United States. Journal of Climate 9, 1111-1125.

Moore, D.M., Reynolds Jr., R.C., 1997. X-ray diffraction and identification and analysis of clay minerals, 2nd edition. Oxford University Press. 378 pp.

National Park Service, 1994. Baseline water quality data, inventory and analysis Yellowstone National Park. National Park Service, Water Resources Division, Tehcnical Report NPS/NRWRD/NRTR-9422. 943 pp.

Persico, L., Meyer, G., 2009. Holocene beaver damming, fluvial geomorphology, and climate in Yellowstone National Park, Wyoming. Quaternary Research 71, 340-353.

Pierce, K.L., 1973. Surficial geologic map of the Mammoth quadrangle and part of the Gardiner quadrangle, Yellowstone National Park, Wyoming and Montana: U.S Geological Survey Miscellaneous Investigations Series Map I-641, scale 1:62,500, with text. 
Pierce, K.L., 1979. History and dynamics of glaciation in the northern Yellowstone National Park area. U.S. Geological Survey Professional Paper, 729 F. 91 pp.

Pierce, J.L., Meyer, G.A., Jull, A.J.T., 2004. Fire-induced erosion and millennial-scale climate change in northern ponderosa pine forests. Nature 432, 87-90.

Pierce, K.L., Cannon, K.P., Meyer, G.A., Trebesch, M.J., Watts, R.D., 2007. Postglacial inflation-deflation cycles, tilting, and faulting in the Yellowstone caldera based on Yellowstone Lake shorelines. In: Morgan, L.A. (Ed.), Integrated geoscience studies in the Greater Yellowstone Area; volcanic, tectonic, and hydrothermal processes in the Yellowstone Geoecosystem: U.S. Geological Survey Professional Paper, 1717, E, pp. 128-168.

Piper, D.Z., Dean, W.E., 2002. Trace-element deposition in the Cariaco Basin under sulfate reducing conditions-a history of the local hydrography and global climate, 20 ka to the present. U. S. Geological Survey Professional Paper, 1670.

Power, M.J., Whitlock, C., Bartlein, P.J., 2011. Postglacial fire, vegetation, and climate history across an elevational gradient in the northern Rocky Mountains, USA and Canada. Quaternary Science Reviews 30, 2520-2533.

Rosenbaum, J.G., Skipp, G., Honke, J., Chapman, C., 2009. A composite depth scale for sediments from Crevice Lake, Montana. U.S. Geological Open-File Report 2009-1277. 5 pp.

Schnurrenberger, D., Russell, J., Kelts, K., 2003. Classification of lacustrine sediments based on sedimentary components. Journal of Paleolimnology 29, 141-154.

Shapley, M.D., Ito, E., Donovan, J.J., 2009. Lateglacial and Holocene hydroclimate inferred from a groundwater flow-through lake, northern Rocky Mountains, USA. The Holocene 19, 523-536.

Shinker, J.J., Bartlein, P.J., Shuman, B., 2006. Synoptic and dynamic climate controls of North American mid-continental aridity. Quaternary Science Reviews 25, 1401-1417.

Shuman, B., Henderson, A., Colman, S.M., Stone, J.R., Fritz, S.C., Stevens, L.R., Power, M.J., Whitlock, C., 2009. Holocene Lake - level trends in the Rocky Mountains, U.S.A. Quaternary Science Reviews 28, 861-1879.

Shuman, B., Pribyl, P., Minckley, T.A., Shinker, J.J., 2010. Rapid hydrologic shifts and prolonged droughts in Rocky Mountain headwaters during the Holocene. Geophysical Research Letters 37, L06701.

Stevens, L., Dean, W., 2008. Geochemical evidence for hydroclimatic variability over the last 2650 years from Crevice Lake in Yellowstone National Park. Quaternary International $188,139-148$.
Stevens, L.R., Stone, J.R., Campbell, J., Fritz, S.C., 2006. A 2200-yr record of hydrologic variability from Foy Lake, Montana, USA, inferred from diatom and geochemical data. Quaternary Research 65, 264-274.

Stone, J.R., Fritz, S.C., 2006. Multidecadal drought and Holocene climate instability in the Rocky Mountains. Geology 34, 409-412.

Stuiver, M., Reimer, P.J., Bard, E., Beck, J.W., Burr, G.S., Hughen, K.A., Kromer, B., McCormac, G., Van der Plicht, J., Spurk, M., 1998. INTCAL98 radiocarbon age calibration, 24,000-0 cal BP. Radiocarbon 40, 1041-1083.

Westerling, A.L., Hidalgo, H.G., Cayan, D.R., Swetnam, T.W., 2006. Warming and earlier spring increase western US forest wildfire activity. Science 313, 940-943.

Whitlock, C., 1993. Postglacial vegetation and climate of Grand Teton and southern Yellowstone National Parks. Ecological Monographs 63, 173-198.

Whitlock, C., Bartlein, P.J., 1993. Spatial variations of Holocene climatic change in the Yellowstone region. Quaternary Research 39, 231-238.

Whitlock, C. Brunelle, A, 2006. Pollen records from northwestern North America. In: Elias, S. (Ed.), Encyclopedia of Quaternary Science. Elsevier, Amsterdam, pp. 1170-1178.

Whitlock, C., Dean, W., Rosenbaum, J., Stevens, L., Fritz, S., Bracht, B., Power, M., 2008. A 2650-year-long record of environmental change from northern Yellowstone National Park based on a comparison of multiple proxy data. Quaternary International 188, 126-138.

Whitlock, C., Briles, C.E., Fernandez, M.C., Gage, J., 2011. Holocene vegetation, fire, and climate history of the Sawtooth Range, central Idaho, USA. Quaternary Research 75, 114-124.

Williams, J.W., Shuman, B., Bartlein, P.J., 2009. Rapid responses of the prairie-forest ecotone to early Holocene aridity in mid-continental North America. Global and Planetary Change 66, 195-207.

Williams, J.W., Shuman, B., Bartlein, P.J., Diffenbaugh, N.S., Webb III, T., 2010. Rapid, time-transgressive, and variable responses to early-Holocene midcontinental drying in North America. Geology 38, 135-138.

Woodhouse, C.A., Overpeck, J.T., 1998. 2000 years of drought variability in the central United States. Bulletin of the American Meteorological Society 79, 2693-2714.

Zdanowicz, C.M., Zielinski, G.A., Germani, M.S., 1999. Mount Mazama eruption: calendrical age verified and atmospheric impact assessed. Geology 27, 621-624. 